LÓPEZ HUGUET, MåL., «El domicilio de las personas jurídicas: evolución desde el Derecho romano y significado actual», REDUR 6, diciembre 2008, pp. 69-94. ISSN I695-078X

\title{
EL DOMICILIO DE LAS PERSONAS JURÍDICAS: EVOLUCIÓN DESDE EL DERECHO ROMANO Y SIGNIFICADO ACTUAL
}

\author{
Ma Luisa LÓPEZ HugUET \\ DOCTORA EN DERECHO \\ UNIVERSIDAD DE LA RIOJA
}

SuMARIO: I. El domicilium en el Derecho romano. II. Evolución en la concepción del domicilio. III. El concepto de persona jurídica: fundamento y admisibilidad. III.I. La teoría de la ficción del Derecho. III.2. La concepción antropomórfica. IV. El domicilio de las personas jurídicas en Derecho romano. V. El domicilio y la nacionalidad de las personas jurídicas en nuestro derecho positivo. VI. Conclusiones.

RESUMEN: El Derecho romano no conoció el concepto de persona jurídica pero sí individualizó determinadas entidades suprapersonales como titulares de derechos y obligaciones cuyo domicilio se concretaba en virtud de su vinculación con el territorio, dentro de cuyos límites actuaban o, en su defecto, a través de sus estatutos o mediante designación por la autoridad pública. En nuestro derecho positivo, las normas específicas regulan el domicilio de las diferentes personas jurídicas aplicándose subsidiariamente el lugar en que se halle establecida su representación legal o donde ejerzan sus principales funciones ex art. 4I CC, considerando españolas aquéllas constituidas conforme al Derecho español que, entre otros requisitos, exige que estén domiciliadas en nuestro territorio ex art. 28 CC.

Palabras ClaVE: Domicilio, persona jurídica, Derecho romano.

TrTLE: The Domicile of the Legal Persons: Evolution from the Roman Law and Present Significance.

ConTENTS: I. Domicile in Roman law. II. Evolution of the domicile's notion. III. Juristic Person: basis and admission. III.I. The theory of the «fiction». III.2. The theory of the «reality». IV. The domicile of the juristic persons in Roman law. V. The domicile and the nationality of the juristic persons in the Spanish Law. VI. Conclusions.

ABSTRACT: In the Roman Law the notion of legal person did not exist, but it attributed to some corpora and universitas capacity to take place certain legal acts. The domicile of the so called legal persons was defined by their territorial liaison or by their statutes or by the public authority. In our law, the specific norms regulate the domicile of the different legal persons. Subsidiary, the article 4I CC fixes their domicile in the place where their legal representation is established or where they develop their principal functions. Moreover, the article $28 \mathrm{CC}$ considers Spanish to the legal persons constituted according to the Spanish Law.

KEYwORDS: Domicile, legal person, Roman law. 


\section{El domicilio en el Derecho romano}

El concepto jurídico de domicilio fue desarrollado en Roma esencial y exclusivamente referido a las personas físicas ${ }^{\mathrm{T}}$. Desde esta perspectiva, el primer vínculo del individuo con el territorio, vino expresado, como hiciera DE FRANCISCI, a través de «la sede de hecho, la habitación material, el lugar en el que cada uno tenía la casa, el hortus», máxime si se tiene en cuenta que el primitivo significado que Festo recoge del término adsiduus era «el que tenía una sede» («Adsiduus dicitur qui in ea re, quam frequenter agit, quasi consedisse videatur») $)^{2}$ y que las distintas fuentes relativas a la inscripción en las tribus aluden incontestablemente a la habitatio o residencia en las mismas. ${ }^{3}$

La sedes, por tanto, simbolizada a través de la domus en cuanto lugar donde se desarrolla estable y materialmente la vida del sujeto sui iuris y de su grupo familiar, constituirá el punto de referencia que la organización estatal de época monárquica y de los primeros siglos de la República tome en consideración para los diferentes fines jurídicos. ${ }^{4}$

\footnotetext{
Sobre el domicilium, vid., con carácter general, GASPARD, A., Recherches sur l'incolat, le droit de bourgeoisie et le domicile, Paris, I851, págs. I ss.; Chavanes, H., Du Domicile, Paris, I863, págs. 52 ss.; AnCelle, A., Du Domicile, Paris, I875, págs. 40 ss.; Roussel, F., Du domicile, en droit romain. De la formation des conventions, en droit international privé, Paris, I878, págs. 5 ss.; Pernice, A., Marcus Antistius Labeo, II.I, Halle, I873, págs. 98 ss.; Baudry, F., s.v. «domicilium», en DS, II.I, Paris, I892, pág. 334; HumberT, G., s.v. «incola», en DS, III, Paris, I900, págs. 457-458; LEONHARD, R., s.v. «domicilium», en PWRE, V, Stuttgart, I905, cols. I299 Ss.; CARNELUTTI, F., «Note critiche intorno ai concetti di domicilio, residenza e dimora», en AG, I905, págs. 396 sS.; BERGER, A., S.v. «incola», en PWRE, IX.2, Stuttgart, I9I6, cols. I249 Ss.; DE RUGGiero, E., La patria nel diritto pubblico romano, Roma, I92I, págs. I69 ss.; DE SAVIGnY, F., Sistema de derecho romano actual, (trad. esp. de J. Mesía y M. Poley), $2^{a}$ edición, VI, Madrid, I924, págs. I54 SS.; TEDESCHI, V., «Contributo allo studio del domicilio in diritto romano», en RISG, 7, I932, págs. 2I3 ss.; idem, Del Domicilio, Padova, I936, págs. I ss.; idem, s.v. «domicilio, residenza e dimora», en NNDI, VI, Torino, I960, págs. I89 ss.; ForCelLINI, A., Lexicon Totius Latinitatis, II, Patavaii, I940 ( $2^{a}$ reimpresión anastática de I965), s.v. «domicilium», págs. I9I ss. y s.v. «domus», págs. I94 SS.; VisContI, A., «Note preliminari sull'"origo' nelle fonti imperiali romane», en Studi di Storia e Diritto in onore di C. Calisse, I, Milano, I939, págs. 87 ss.; idem, «Note preliminari sul 'domicilium' nelle fonti romane», en Studi in onore di C. Ferrini in occasione della sua beatificazione, I, I947, págs. 429 ss.; AYITER, K., «Einige Bemerkungen zum Domicilium des Filius Familias in römischen Recht», en Studi Betti, II, Milano, I962, págs. 7I ss.; ZILlETTI, U., s.v. «incolato (Diritto romano)», en NNDI, VIII, Torino, I962, págs. 54I-542; NöRR, D., «Origo. Studien zur Orts-, Stadt- und Reichszugehörigkeit in der Antike», en $R D H$, 3I, I963, págs. 528 ss.; idem, s.v. «origo», en PWRE, Suppl. Bnd. X, Stuttgart, I965, cols. 433 SS.; BuRDESE, A., s.v. «domicilio (Diritto romano)», en ED, XIII, Milano, I964, págs. 837-838; Grossi, P., s.v. «domicilio (Diritto intermedio)», en ED, XIII, Milano, I964, pág. 840; Bruguiere, M.B., «Le domicile dans les droits antiques», en Mélanges dédiés à Gabriel Marty, Tolouse, I979, págs. I99 ss.; SALGADo, J., «Contribución al estudio del 'domicilium' en el Derecho romano», en RDP, LXIV (Enero-Diciembre I980), Madrid, I980, págs. 495 ss.; THomAS, Y., «Origine» et «Commune Patrie». Étude de Droit Public Romain (89 av. J.-C. - 212 ap. J.-C.), Paris, Rome, I996, págs. 34 Ss.; BACCARI, M.P., Cittadini popoli e comunione nella legislazione dei secoli IV-VI, Torino, I996, págs. 79 Ss.; LICANDRO, O., Domicilium habere. Persona e territorio nella disciplina del domicilio romano, Torino, 2004, passim; GAGLIARDI, L., Mobilità $e$ integrazione delle persone nei centri cittadini romani. Aspetti giuridici. I. La classificazione degli incolae, Milano, 2006, passim; LÓPEZ HUGUET, $M^{a}$ L., «Un estudio sobre la configuración jurídica del término domicilium en Derecho romano», en $R G D R$ (www.iustel.com), $\mathrm{n}^{\circ}$ 8, junio, 2007, págs. I ss.; idem, Régimen jurídico del domicilio en Derecho Romano, Dykinson, 2008, passim.
}

${ }^{2}$ Festo, De verborum significatu, (ed. Lindsay 8) s.v. «adsiduus». De Francisci, P., Primordia Civitatis, Roma, I959, págs. 679-680, el autor precisa que sólo con posterioridad el término adquirió el significado de propietario fundiario. En este sentido, NicosiA, G., Il processo privato romano. II. La regolamentazione decenvirale. Corso di diritto romano, Torino, I986, págs. 46 ss.; AlBAnESE, B., «Osservazioni su XII tab. I.4: il 'vindex' per ‘adsidui' e 'proletarii'», en Index, 26, I998, págs. 22 ss.; LiCANDRO, Domicilium habere..., cit., págs. 47-48. Cfr. GAGLIARDI, Mobilità..., cit., pág. 333, que habla directamente de propietario fundiario.

3 Tito Livio, Ab urbe condita, I.43.I3: «Quadrifariam enim urbe divisa regionibus collibusque qui habitabantur, partes eas tribus appellavit»; PLINIO EL VIEJO, Naturalis Historia, I8.I3.3: «... quattuor erant a partibus urbis in quibus habitabant, Suburana, Palatina, Collina, Esquilina»; Papiro de Oxyrinco, I7.2088: «postea in oppido qui [ [o] ]osque pago civis ha[bitabat/] exque pagis milites conquirebantu[r et tributum?».

${ }^{4}$ Sobre el significado de sedes relativo a la idea de establecimiento y morada, identificándose en el lenguaje jurídico con el domicilium, ERnout, A.-Meillet, A., Dictionnaire Étimologique de la Langue Latine. Histoire des Mots, Paris, I967, 5 a edición, s.v. «sedeo», págs. 609-6II; WALDE, A.-HofmANn, J.B., Lateinisches Etymologisches 
Pero la política expansionista romana y, con ella, el otorgamiento de diferentes grados de ciudadanía a los territorios conquistados, la mejora de los medios de comunicación y el desarrollo de los intercambios comerciales facilitaron la movilidad del individuo, permitiéndole rebasar con sus actuaciones el ámbito delimitado por la domus familiar y asentarse en un lugar distinto al de su origen. ${ }^{5}$ Ello comportó, a juicio de THOMAS, que el hecho material de la habitatio se desligara de las vinculaciones sociales que la domus representaba, la cual englobaba en su contenido tanto la casa entendida como habitáculo, edificio y propiedad, como la residencia habitual, la propia familia e incluso la patria. ${ }^{6}$

Esta desvinculación provocó la derivación semántica de domus a domicilium, ${ }^{7}$ término que ya se presenta en el siglo II a. C. ${ }^{8}$ como una noción jurídica autónoma que

Wörterbuch, Heidelberg, I982 (reimpresión de la edición de Heidelberg, I822), vol., II, s.v. «sedeo», págs. 507509; Bonjour, M., Terre Natale. Études sur una composante affective du patriotisme romain, Paris, I975, pág. 56 ss.

${ }^{5}$ Sobre el desarrollo del comercio, entre otros, GARZETTI, A., «Appio Claudio Cieco nella storia politica del suo tempo», en Athenaeum, 25, I947, pág. I89; Juglar, L., Du rôle des esclaves et des affranchis dans le commerce, Rome, I972 (reimpresión de la edición de Paris, I884), págs. XVI-XVII y págs. I ss.; LuRAsCHI, G., Foedus Ius Latii Civitas. Aspetti costituzionali della romanizzazione in Transpadana, Padova, I979, págs. 7 ss.; KIRSCHEBAUM, A., Sons, Slaves and Freedmen in Roman Commerce, Jerusalem, Washinton, I987, págs. 90 ss.; FADDA, C., Istituti commerciali di diritto romano. Introduzione, Napoli, Paris, I987, págs. Io ss.; GARCÍA GARRIDO, M., El comercio, los negocios y las finanzas en el mundo romano, Madrid, 200I, págs. I8-30.

${ }^{6}$ Thomas, «Origine» et «Commune Patrie»..., cit., págs. 37 ss. Sobre la pluralidad de significados y vinculaciones sociales del término domus vid., entre otros, Rivier, A., Précis de Droit de famille romain, Paris, I89I, pág. 3 n. 8; Thesaurus Linguae Latinae, Vol. 5.I, Fasc. VII, Lipsiae, I9I5, cols. I949 ss., s.v. «domus»; CosTA, E., Cicerone giurisconsulto, I, Bologna, I927 (edición anastática, Roma, I964), pág. 49 y n. 2; CollinET, P.Giffard, A., Précis de Droit Romain, I, $3^{\text {a }}$ edición, Paris, I930, pág. I73; PARIBENI, R., La famiglia romana, $4^{\mathrm{a}}$ edición, Bologna, I948, pág. 56; DE RUGGieRo, La patria..., cit., págs. I3 ss. y págs. I75-I76; Vocabularium Iurisprudentiae Romanae, II, Berolini, I933, s.v., «domicilium», col. 334 y s.v. «domus», cols. 374-378; CALZA, G., s.v. «domus», en De Ruggiero, E., Dizionario Epigrafico di Antichità Romane, vol. II.3, Roma, I96I, págs. 2046 ss.; ForCELlini, Lexicon Totius Latinitatis, vol. II, s.v. «domus», cit., págs. I94-I95; ERNOUT-MEILLET, Dictionnaire Étimologique de la Langue Latine. Histoire des Mots, cit., s.v. «domus», págs. I82-I83; WALDE, A.-HofMANN, J.B., Lateinisches Etymologisches Wörterbuch, $5^{\mathrm{a}}$ edición, Heidelberg, I982 (reimpresión de la edición de Heidelberg, I822), vol. I, S.v. «domus», págs. 369-370; DE FranCisci, Primordia Civitatis, cit., pág. I33 y pág. I39; BonJOUR, Terre Natale..., cit., págs. 50 SS.; SALLER, R.P., «'Familia', 'domus', and the roman conception of the family», en Phoenix, 38, Toronto, I984, págs. 342 ss.; BACCARI, Cittadini..., cit., págs. 79 ss.; HillnER, J., «Domus, Family and Inheritace: the Senatorial Family House in Late Antique Rome», en JRS, 93, 2003, págs. I29 ss.

${ }^{7}$ Desde el punto de vista etimológico se supone que la expresión domicilium deriva del término domi-cola, proveniente de domum colere. Sobre la derivación etimológica del domicilium, entre otros, BATTISTA, M., Del domicilio e della residenza, dell'assenza, dell'influenza delle condanne penali sulla capacità civile (segundo libro de la obra Il Diritto civile italiano, inicialmente dirigida por P. Fiore y continuada por B. Brugi), $2^{\mathrm{a}}$ edición revisada, Napoli, I923, pág. 5I; TEDESCHI, «Contributo...», cit., pág. 223 n. I; ForCELlINI, Lexicon Totius Latinitatis, vol. II, cit., s.v. «domicilium», págs. I9I-I92; ERNOUT-MEILlET, Dictionnaire Étimologique de la Langue Latine. Histoire des Mots, cit., s.v. «colo» pág. I32 y s.v. «domus» pág. I83; BURDESE, s.v. «domicilio (Diritto romano)», cit., págs. 837838; Bonjour, Terre Natale..., cit., págs. 56-57; SAlGAdo, «Contribución...», cit., págs. 495; WALdE-HofmAnN, Lateinisches Etymologisches Wörterbuch, I, cit., s.v. «domicilium» pág. 367 y s.v. «domus», págs. 369 ss.; LiCANDro, Domicilium habere..., cit., pág. 82 n. 86; BACCARI, Cittadini..., cit., págs. 79 ss.; Segura Munguía, S., Nuevo diccionario etimológico Latín-Español $y$ de las voces derivadas, Bilbao, 200I, págs. 234-235; GAGLIARDI, Mobilità..., cit., pág. 332.

${ }^{8}$ Es predominante en la doctrina la defensa de una aparición relativamente tardía de la noción autónoma del domicilium, que ha venido en buena medida motivada por un análisis centrado en las fuentes jurídicas, en detrimento de la información proporcionada por los testimonios literarios o epigráficos, que se ha traducido en la afirmación de que, si bien el término domicilium era ya conocido con anterioridad, hasta el siglo I a. C., según las teorías más revolucionarias, no se produjo una verdadera y propia reflexión jurídica sobre el instituto. El principal argumento de estos autores reside en el hecho de que en esta época, comprendida entre el siglo I a. C. y el siglo III d. C., son numerosas las fuentes jurídicas que atribuyen a domus el significado de domicilium (D. 50.16.203) o que especifican que por domus debe entenderse el domicilium (D. 47.IO.5.I; 48.5.22.2; iI.5.I.2), lo que ha sido interpretado como una fase de transición, en la que el específico concepto de domicilium todavía no se había desligado del más genérico concepto de domus. Sin embargo, la primera constancia que tenemos del vocablo domicilium se encuentra en una comedia de Plauto, el Militar Fanfarrón, con un significado distinto al de domus, en este caso utilizado para indicar el lugar de procedencia (Plauto, Miles gloriosus, 2.450). Esta obra, 
expresaba la residencia estable del individuo, con independencia de toda modalidad de propiedad o habitación, que constituía con carácter general el centro de sus actividades vitales y negociales y cuya determinación requería la concurrencia de dos elementos: el corpus o elemento material, consistente en el establecimiento efectivo; y el animus o elemento intencional, que hacía referencia a la voluntad real y actual de permanencia. ${ }^{9}$ La conjunción de ambos elementos permitía que dicha estabilidad fuera compatible con ausencias temporales y, por otro, no excluía un ulterior traslado domiciliario. No obstante, para el mismo, igual que para su constitución, no bastaba una mera declaración de voluntad, ni la simple posesión de un edificio o fundo, sino que era necesario el establecimiento real en el lugar libremente elegido, normalmente expresado mediante la constitutio laris y la constitutio rerum ac fortunam. ${ }^{\text {. }}$

Por otro lado, los requisitos constitutivos del domicilio comportaban que, con carácter general, éste fuese único. Sin embargo muy pronto se admitió que, de forma excepcional, una persona pudiera tener una pluralidad de domicilios cuando estuviera establecida por igual en ambos lugares. Y con el mismo carácter excepcional se admitió que pudiera carecer de domicilio cuando, habiendo abandonado el actual, se encontrase buscando otro o se dedicase a viajar durante largo tiempo.

datada en el año 204 a. C., nos permite afirmar que el término era ya conocido, al menos, en el lenguaje popular. Asimismo, pocos años después, encontramos el mismo en distintas fuentes epigráficas y literarias de los siglos II a. C. y I a. C. , en las que se alude al domicilio con ocasión de los licenciamientos de los soldados (César, Bellum Civile, i.87.4), respecto al acceso a la ciudadanía romana, en relación con la inscripción en el censo (Cicerón, pro Archia, 4.7 ss.; Tabula Heracleensis, lns. I57-I58) o como requisito impuesto a los candidatos para acceder a determinados cargos públicos locales (Lex Acilia repetundarum, lns. I3-I4; Lex municipii Tarentini, lns. 26-3I; Lex coloniae Genetivae seu Ursonensis, cap. 9I; Aulo Gellio, Noctes Atticae, I.I2.8), sin especificar más, es decir, estas normas establecen la obligación legal de tener el domicilio en la comunidad para acceder a determinados cargos públicos o aluden al mismo en relación con diversos fines político-jurídicos sin precisar qué debe entenderse por domicilio, lo cual nos induce a pensar que el mismo, no sólo era conocido en el lenguaje común, sino que también había sido objeto de una reflexión jurídica ya terminada. Esta configuración autónoma de la noción de domicilium en el siglo II a. C. es perfectamente compatible con el hecho de que los jurisconsultos clásicos, a la hora de interpretar determinadas leyes de la época republicana expliquen que domus debe entenderse en el sentido de domicilio. En efecto, la ausencia de referencia al domicilium no es debida a una derivación semántica domus-domicilium todavía inacabada, sino a la propia neutralidad y ambigüedad del legislador republicano que habría preferido el más genérico y común término domus, de ahí que fuera necesaria la intervención de los prudentes para su interpretación, extrayendo de dicha noción el más restrictivo concepto de domicilium y diferenciándolo, a su vez, de la mera casa en propiedad y de la simple habitatio, lo cual denota un conocimiento extraordinariamente preciso de su significado que difícilmente puede sustentar la hipótesis de que, en esta época, sus contornos no estuvieran perfectamente delimitados, sino todo lo contrario, esto es, que el concepto de domicilium era un concepto consabido, concreto y asumido normativamente con anterioridad. Al respecto, LÓPEZ HUGUET, «Un estudio sobre la configuración jurídica del término domicilium en Derecho romano», cit., págs. I ss.; idem, Régimen jurídico del domicilio en Derecho Romano, cit., págs. 5I Ss.

${ }^{9}$ Lógicamente, quedan exceptuados de esta definición los supuestos de domicilio legal o necesario, sobre los cuales, LICANDRO, Domicilium habere..., cit., págs. 34I ss.

${ }^{10}$ LÓPEZ HugUET, «Un estudio sobre la configuración jurídica del término domicilium en Derecho romano», cit., págs. I ss.; idem, Régimen jurídico del domicilio en Derecho Romano, cit., págs. 5I ss., Frente a la teoría evolutiva de Pernice, para quien, hasta la época de Adriano, no entró en juego el elemento intencional, siendo el domicilio exclusivamente delimitado por la residencia material, en nuestra opinión, desde su configuración jurídica en el siglo II a. C., el mismo vino concretado a través de los dos elementos. Asimismo, en contra de la opinión de Leonhard, quien postula una fase evolutiva posterior en la que el domicilio venía constituido por el centro de los negocios, consideramos que ese centro, al igual que el centro de las actividades vitales, acompañaban normalmente al establecimiento efectivo del individuo y lejos de constituir por sí solos el domicilio, son una consecuencia del mismo.

${ }^{\text {II }}$ Tabula Heracleensis, lns. I57-I58; D. 50.I.5; D. 50.I.6『2; D. 47.IO.5『5. 


\section{Evolución en la concepción del domicilio}

En las legislaciones posteriores, afirma SAVIGNY, el domicilio alcanzó una importancia esencial, dado que cada ciudad se regía por su propio estatuto, el cual regulaba a su modo los derechos correspondientes al individuo, la capacidad y las condiciones jurídicas de las cosas y los singulares derechos que sobre las mismas podían ser adquiridos, o la facultad de disponer a título oneroso o gratuito o de transmitir por sucesión. Las disposiciones sobre tales materias a menudo eran diferentes en los diversos estatutos, los cuales, por tanto, se encontraban en conflicto constante. Para solucionarlos la relación del individuo con la ley se estableció a través del domicilio, de tal forma que era la ley del domicilio la que determinaba el estatuto personal y la relación con sus bienes. ${ }^{\text {I2 }}$ Sólo con la consolidación de los Estados modernos, el concepto de nacionalidad sustituirá al domicilio en el papel principal de la determinación del estatuto personal.

Pero desde el derecho romano hasta nuestro días el concepto de domicilio ha sufrido importantes transformaciones. En el medievo, señala BATTISTA, el domicilio tuvo, en sustancia, la misma configuración que en el derecho romano. Los glosadores, en efecto, no hicieron sino repetir la teoría romana, pero insistiendo todavía más en la distinción entre los dos elementos, el material de la habitación y el intencional del animus que podía ser demostrado de diversas formas y no sólo a través de la constitutio laris y de la constitutio rerum ac fortunam en un determinado lugar: animus recedendi, longa o assidua habitatio, de tal forma que se incrementaron los supuestos en los que la habitación o morada no coincidía con el centro de los negocios e intereses del individuo. ${ }^{\mathrm{I3}}$

\footnotetext{
${ }^{12}$ SAVIGNY, Sistema..., VI, cit., págs. I2I ss., analiza los conflictos existentes entre los diferentes derechos de las ciudades pertenecientes a un mismo estado, entre los derechos locales y el derecho del estado mismo o entre los derechos de estados distintos. En el primer caso, la solución sería aplicar la ley del domicilio, en el segundo la ley local ya que la misma ha sido autorizada por el estado, en el tercero el problema vendría resuelto por los tratados internacionales. Sobre el tema, vid., ORLANDI, G., s.v. «domicilio, residenza e dimora», en Il Digesto Italiano, IX.3, Torino, I927, págs. 655 ss.; BATTISTA, Del domicilio..., cit., págs. I2-13, quien señala que se discutía si debía considerarse como ley personal aquélla del domicilio de origen o la del domicilio actual de la persona, controversia que asumía una mayor importancia en el caso de cambio de domicilio, dudándose de si se debía aplicar la ley del domicilio abandonado o la del nuevo. A este respecto, TEDESCHI, Del Domicilio, cit., págs. 5I SS., precisa que la ficción de que en el lugar de la origo se tenía un domicilio proviene de los glosadores, y en caso de conflicto entre domicilium originis y domicilium habitationis, éste primaba, aunque dicha primacía estaba en realidad atenuada por la presunción de vinculación hacia el lugar de origen, la cual hace que los requisitos para el establecimiento del domicilio en otro lugar sean verdaderamente exigentes y difíciles de cumplir; GrossI, s.v. «domicilio (Diritto intermedio)», cit., págs. 840.
}

${ }^{\mathrm{r} 3}$ BATTISTA, Del domicilio..., cit., págs. IO-I2, donde recoge a este respecto las paráfrasis, glosas y comentarios de Accursio, Bártolo, Baldo, Aliciato y Donello: «Accursio -Digestum novum, ad leg. 27 y 28 h. t.- parafrasea los pasajes de Ulpiano (D. 50.I.27.I-2): 'item qui in municipio moratur: ibi emit, ibi contrahit, ibi dies festos celebrat, in colonia ubi sunt agri sui non moratur nisi raro; dicitur habere domicilium in municipium'. Bártolo - Opera omnia, vol. VII- hace referencia específicamente a los dos elementos gracias a los que se puede adquirir el domicilio: 'uno modo voluntate...; alio modo reipsa stando in loco ubi habet majorem partem patrimonium suorum'. Baldo -Consilia sive responsa, Cons. 3II, vol. IV, 62- también insiste sobre la habitación y sobre el animus perpetuo manendi: 'In constitutione autem domicilii animus et factum requiritur, ut l. domicilium ff. ad municipi., et habitatio requiritur inter venire eo animo est perpetuo ibi si maneat'; y añade que el ánimo 'ex praesumptionibus probatur'. No menos claramente los indica Aliciato -Commentaria, II, col. I270-, especialmente señalando los factores exteriores de los cuales se presume el animus perpetuo manendi: 'ex varii coniecturis sumitur, qui enim venditis, quas alibi possidebat, rebus suis, in aliam urbem cum familia demigravit, verisimile est sedem in ea suam constituere velle'. Por último Donello -Opera omnia, De iure civili, lib. XVII, cap. XII 『III- extrae de las fuentes con mayor precisión el concepto entero de domicilio en sus dos elementos constitutivos: 'domicilium cujusque privatum recte definietur; ut sit locus in quo quis habitat eo animo ut ibi perpetuo consistat nisi quid avocet... Habitatio non est satis, animum consistendi accidere oportet'. Y este ánimo o intención se revela 'ex muniis vitae quotidianae quae quis alicubi obeat', esto es, del hecho de disfrutar en un lugar de las comodidades de la vida (forum, balneum, spectaculia...) 'et ex ordine et conditione personae', como en los casos del estudiante, del soldado, del condenado a la relegación, de la mujer, los cuales tienen un domicilio necesario». El análisis de estos textos conduce a BATTISTA a afirmar que también en el medievo el domicilio tuvo por fundamento la residencia estable en un lugar, si bien, dicha estabilidad podía ser demostrada de otras formas. El autor sigue en este sentido a CARNELUTTI, «Note critiche...», 
En el mismo sentido se manifiesta GROSSI, para quien la residencia prolongada, el ejercicio de la propia actividad o de funciones públicas, la situación de la mayor parte de los bienes, o de la empresa comercial o de la familia constituían presunciones iuris tantum o indicios exteriores del elemento intencional, tanto para la conservación del domicilio, como para su cambio. ${ }^{\mathrm{IH}}$

Con mayor detalle profundiza en esta idea TEDESCHI. De acuerdo con su planteamiento, «si de los dos elementos mencionados, para la constitución del domicilio la habitatio es necesario, fundamental es el segundo, el animus, del que la perpetuitas es cualidad inseparable. Y hasta tal punto es fundamental que terminará por dejar en la sombra al primero. Si la intención está presente, no es necesaria ni la morada prolongada, ni el traslado en el lugar de la mayor parte de los bienes, ni el traslado del centro de los negocios... que no son sino presunciones de la existencia del animus. Pero, si la intención falta, no hay circunstancia que valga para retener constituido el domicilio». Asimismo, la función del animus se manifiesta todavía más relevante en la conservación del domicilio puesto que, en el derecho intermedio, se permitió conservarlo solo animo, a pesar del alejamiento prolongado de la persona, lo cual dificultó el abandono del domicilio del lugar de nacimiento y la adquisición de uno nuevo, porque quien se separaba del domicilio de origen conservaba generalmente un animus revertendi. Ello generó que no fuera extraño que se conservara el domicilio primitivo aunque la persona estuviera establecida en un lugar distinto, distinguiéndose entre domicilium originis, domicilium habitationis y domicilium bonorum. Y esta concepción del domicilio, admitida en sus elementos sustanciales por el derecho canónico, se ha dilatado en el mundo jurídico contemporáneo gracias a la identidad de fines a cumplir. ${ }^{15}$

No obstante, esta abstracción del concepto de domicilio fue acogida de forma distinta en el proceso de codificación del derecho positivo en que desemboca en ius naturalismo en la Francia de los siglos XVII y XVIII y posteriormente en el resto de los códigos de las naciones europeas.

En efecto, en el Código Civil napoleónico de $\mathrm{I} 804,{ }^{\mathrm{I}}{ }^{6}$ el legislador esgrimió en su artículo io2 el concepto de «principal establecimiento», haciendo coincidir la habitación y el centro de los negocios e intereses. Pero estos dos elementos, a juicio de CARNELUTTI, no concurrían de la misma forma en la constitución del elemento material del domicilio: la habitación era el exclusivo elemento material, mientras que el otro no era sino la manifestación tácita e indirecta del animus permanendi. Por tanto, aunque el domicilio francés fue siempre la morada estable, la residencia fija, esta estabilidad no era valorada a través de su existencia material o física, sino mediante el elemento intencional. ${ }^{\text {I7 }}$

Empero, continúa CARNELUTTI, el Código napoleónico se manifestaba anacrónico porque en su art. I03, al hablar del cambio de domicilio, no separaba la constitutio rerum de la demora, haciéndola en cambio coincidir en el establecimiento principal. Este error sólo se observará más tarde, cuando, en el siglo de los descubrimientos, se revoluciona todo el

cit., págs. 404 Ss., para quien el elemento intencional se podía manifestar expresa o tácitamente, siempre salvo prueba en contrario. Por su parte, ORLANDI, s.v. «domicilio, residenza e dimora», cit., pág. 655, señala que, a pesar de que en el medievo los dos requisitos se seguían exigiendo, el elemento intencional fue adquiriendo un mayor protagonismo.

${ }^{\text {I4 }}$ Grossi, s.v. «domicilio (Diritto intermadio)», cit., pág.840 ; CARNELUTTI, «Note critiche...», cit., págs. 404 ss., afirma que en el derecho común se relativizó la importancia de la constitutio rerum et fortunarum, limitada a ser solamente un indicio exterior del animus permanendi.

${ }^{15}$ En este sentido, Tedeschi, Del Domicilio, cit., págs. 9-67.

${ }^{16}$ Sobre la discusión parlamentaria relativa a la introducción en el Código napoleónico de un título sobre el domicilio, ORLANDI, s.v. «domicilio, residenza e dimora», cit., pág. 656.

${ }^{17}$ CARnElutTI, «Note critiche...», cit., págs. 404 ss. 
sistema de los medios de comunicación y de transporte: el establecimiento de la persona se diferenciaba del establecimiento de sus negocios e intereses, como el domicilio romano se diferenciaba de la mera habitación. Así, se opera una última transformación del concepto concretada en el doble fenómeno del surgimiento del concepto autónomo de residencia como morada estable y habitual y de la transformación de la constitutio rerum et fortunarum, de índice externo del elemento intencional del domicilio a verdadero elemento material y único del mismo: ahora no se concebía ya la habitación o la morada como elemento integrante o necesario del domicilio; éste aparecía como algo autónomo y existente, incluso sin la habitación, sostenido por la base real y viva de la sede de los negocios e intereses. ${ }^{18}$

Pero este planteamiento chocaba con los arts. I02 y I03 del Código Civil napoleónico que concebían la morada como un elemento esencial del domicilio. Por tanto, para adaptar la norma de la ley a la realidad de la vida, la doctrina francesa creó la regla de la «esencia puramente jurídica» del domicilio, esto es, la contraposición entre el domicilio como res iuris y la residencia como res facti. De esto modo, el domicilio fue considerado como una res ficta que la ley creó, no era el lugar donde una persona se encontraba realmente o normalmente, sino donde la ley fingía que se encontraba, donde la ley presumía que estaba presente, por la necesidad jurídica de atribuir una sede fija a la persona. Y correlativamente a la idea de la fictio iuris, se maduró la regla, según la cual, el domicilium nudo animo retinetur, con independencia de la morada. ${ }^{19}$

Diferencias importantes se aprecian, sin embargo, entre la doctrina alemana de la escuela histórica del derecho y de la pandectística. En efecto, mientras SAVIGNY sigue una «conceptualización» del domicilio fiel al derecho romano considerando que era «el lugar en donde -una persona- reside constantemente y que -en consecuencia- ha elegido libremente como centro de sus negocios y de sus relaciones jurídicas», ${ }^{20}$ pandectistas como DERNBURG o PUCHTA generalizaron la calificación del domicilio como el lugar que constituía el centro de vida cívica y de los negocios del individuo. ${ }^{21}$ No obstante, afirma ORLANI, la codificación alemana del año igoo prefirió optar por el término Wokusitz (léase Wonhsitz) que se corresponde más a residencia que a domicilio, haciendo prevalecer, por tanto, el criterio del establecimiento (Ständig) físico del individuo. ${ }^{22}$ Pero, incluso así, como indica MANRESA, el elemento intencional continúa siendo imprescindible de cara al traslado domiciliario. ${ }^{23}$

Distinta definición encontramos en el art. 43 del Código Civil italiano que, como señalan CIAN y TRABUCCHI, diferencia entre domicilio y residencia de la persona, calificando al primero como «el lugar en el que tiene la sede principal de los negocios e intereses» y al segundo como «el lugar en el tiene la morada habitual». Para estos autores, la noción de domicilio consta de un elemento objetivo -la concentración de los negocios e intereses- y de un elemento subjetivo -la intención de concentrar tales negocios e intereses en ese lugar- que puede ser manifestado expresamente o deducido de los actos de la persona. En todo caso, la expresión «negocios e intereses» es empleada en un sentido económico no teniendo nada que ver con las relaciones familiares o sociales de modo que, aunque el domicilio tiende a coincidir con la residencia, puede no ser así y si el individuo

\footnotetext{
${ }^{18}$ CARnElUTTI, «Note critiche...», cit., págs. 404 SS.

${ }^{\text {I9 }}$ CARNELUTTI, «Note critiche...», cit., págs. 404 SS.

${ }^{20}$ SAVignY, Sistema..., VI, cit., pág. I55.

${ }^{21}$ Dernburg, H., Pandekten, I, Berlin, i896, pág. I04; PuChTA, G. F., Pandekten, Leipzig, i845, pág. 65; DE ARENSBerG, L.A.R., Lehrbuch der Pandekten, Stuttgart, I877, pág. 40.

${ }^{22}$ OrLANDI, s.v. «domicilio, residenza e dimora», cit., pág. 658. Arts. 7 Ss. BGB. Art. 7: «Wer sich an einem Orte ständig niederlässt, begründet an diesem Orte seinem Wohnsitz».

${ }^{23}$ Art. 7.III. BGB: «Der Wohnsitz wird aufgehoben, wenn die Niederlassung mit dem Willen aufgehoben wird, sie aufzugeben». MANResa y NAVARro, J.M., Comentarios al Código Civil Español, I, Madrid, I987, págs. 387 ss. Al respecto, AA.VV., Palandt Bürgerliches Gesetzbuch, Band 7, 5I Auflage, München, I992, págs. Io ss.
} 
cambia su sede principal, allí tendrá el domicilio. ${ }^{24}$ No obstante, como recogen tales autores, la desvinculación entre el domicilio y la residencia viene contrastada con el artículo 44 en el que se establece que si ambos coinciden, frente a terceros, el cambio de residencia implicará el cambio de domicilio. ${ }^{25}$

Esta contradicción ya había sido puesta de manifiesto por CARNELUTTI en relación con los artículos I6 (actual art. 43) y I7 (actual 44) del Código Civil Italiano de I865. El primero, en su opinión, representaba la fase posterior lógica en la evolución del domicilio efectuada por la doctrina francesa, en el sentido de desvincular completamente al mismo del elemento de la morada y apoyarlo sustancialmente en el elemento de la actividad moral y social de la persona. Lamentablemente, los legisladores no fueron conscientes de esta innovación y, creyendo que el domicilio italiano era el mismo que el francés, en el art. I7 reprodujeron el art. I03 del Código napoleónico, relativo al traslado de domicilio. Craso error, porque mientras el domicilio francés era, como el domicilio romano, definido a través de la morada estable medida por la intención de tener allí el centro de la propia actividad social -de tal forma que un traslado de domicilio exigía una habitación real, junto con la intención de tener el principal establecimiento en el nuevo lugar-, el domicilio italiano no resultaba ya de la concurrencia de los dos elementos (residencia e intención del principal establecimiento), si no sólo de la sede principal de los intereses. «Existe -concluye el autoruna contradicción entre el art. I6 y el art. I7 del Código civil italiano, norma esta última anacrónica y antinómica que ha dado origen a que la evolución histórica y lógica del domicilio quede incompleta».

Nuestro Código Civil se elaboró en un momento en el que ya la doctrina francesa, acorde con la realidad de los tiempos había elaborado el concepto de residencia y desligado el domicilio de la morada habitual, identificándolo con el centro de los negocios para, posteriormente, configurarlo como la sede jurídica del individuo. Sin embargo, manifestando un cierto conservadurismo, nuestro legislador hizo confluir en el artículo 40, esa concepción del domicilio como centro de imputación de derechos y obligaciones con su identificación con la residencia habitual del individuo. ${ }^{27}$

Bajo esta aparente simplicidad, en cambio, como ha puesto de manifiesto PARRA LUCÁN, nos encontramos con un concepto oscuro y complejo que engloba una pluralidad de significados como se constata en las referencias que al domicilio y a la residencia se realizan en los diferentes textos normativos de las diversas ramas de nuestro ordenamiento jurídico.

${ }^{24}$ Art. 43 CC italiano: «Il domicilio di una persona è nel luogo in cui essa ha stabilito la sede principale dei suoi affari e interessi. La residenza è nel luogo in cui la persona ha la dimora abituale». CiAN, G.-TRABUCCHI, A., Comentario breve al Codice civile, $5^{\text {a }}$ edición, Milano, 1997, págs. 25I Ss.

${ }^{25}$ Cian-Trabucchi, Comentario breve al Codice civile, cit., págs. 25I ss.

${ }^{26}$ CARnElutTI, «Note critiche...», cit., págs. 404 ss., en su opinión, el domicilio no puede ser calificado de una fictio iuris porque presenta un elemento material indiscutible, determinado por la sede de los negocios e intereses. La presunción se ha dicho, radica en el hecho de que el Derecho presume que en esa sede, la persona está presente pero, a juicio del autor, el domicilio italiano no es la sede de la persona sino la de sus intereses y negocios, aunque no habite allí, siendo esa presunción innecesaria. El domicilio es una realidad, lo que no excluye que, ocasiones, la ley establezca un domicilio ficticio (domicilio legal). Al respecto, vid., también, ORLANDI, s.v. «domicilio, residenza e dimora», cit., pág. 656 ss.; MANRESA Y NAVARRo, Comentarios al Código Civil Español, I, cit., págs. 387 ss., sobre la regulación del domicilio en las legislaciones de otros estados europeos, como en el derecho inglés que exige una residencia de cuarenta días.

${ }^{27}$ Art. 40 CC: «Para el ejercicio de los derechos y el cumplimiento de las obligaciones civiles, el domicilio de las personas naturales es el lugar de su residencia habitual y, en su caso, el que determine la Ley de Enjuiciamiento Civil». 
En relación a cada norma, por tanto, el lugar que debe considerarse como domicilio de la persona dependerá de la finalidad que se pretenda conseguir. ${ }^{28}$

En efecto, hoy en día, la doctrina en general, acepta que el domicilio es la sede jurídica de las personas que la ley toma en consideración para su localización jurídica y que, precisamente por servir al derecho para ubicar la situación jurídica global de la persona, se contrapone a la noción de residencia inestable, siendo caracterizado por un elemento material -la residencia- y uno espiritual -la habitualidad- ${ }^{29}$ Algunos autores, en cambio, entienden que seguir la concepción romana de corpus y animus es incompatible con la realidad económica del individuo y postulan abandonar el elemento intencional o animus, entendiendo que «habitual» no debe ser entendido como animus perpetuo manendi, sino como «normal y de presumible continuación», requisito que debe reunir el corpus, único elemento preciso. ${ }^{30}$ Asimismo no faltan definiciones de domicilio que atienden a criterios económicos como la sede principal de los negocios e intereses, mientras se considera que la residencia es simplemente el lugar donde una persona vive habitualmente. E incluso encontramos autores que consideran que el domicilio constituye un vínculo de Derecho entre la persona y el lugar (vínculo más o menos intenso en función de la duración en el tiempo y de los intereses que le unan a ese lugar), ${ }^{3 \mathrm{I}}$ mientras que la residencia es una relación fáctica. ${ }^{32}$

En realidad esta pluralidad de definiciones se explica porque el domicilio, como dice Álvarez ÁlVAREZ siguiendo a DE CASTRO, se puede definir siguiendo un doble criterio: atendiendo a los requisitos que un lugar ha de tener para ser domicilio o atendiendo a la eficacia jurídica que se atribuye al mismo. Así, observamos que el art. 40 del CC conjuga ambos criterios, pero dotando de una mayor importancia al primero, puesto caracteriza al domicilio como el lugar de la residencia habitual, en cuanto medio principal para la localización jurídica del individuo. A juicio de DE CASTRO, el domicilio presenta tres caracteres: el personal, en cuanto predicable de cualquier persona con independencia de sus bienes; el realista, que atiende al hecho real de la residencia; y el concreto, que delimita su espacio físico de acción y viene determinado por las normas específicas (pueblo -art. 749 CC-, provincia -art. 747 CC-, Comunidad Autónoma -art. I4.5 CC-, Estado -arts. I7 ss. CC-..... ${ }^{33}$ Y ello, como precisa LACRUZ BERDEJO, para proteger, no sólo los intereses de la persona, sino también los de terceros que se relacionan con ella. ${ }^{34}$

\footnotetext{
${ }^{28}$ PARra LuCÁn, Ma .A., «Nombre y domicilio», en AA.VV., Curso de Derecho Civil, I, Derecho Privado. Derecho de la Persona, $2^{a}$ edición, Madrid, 200I, capítulo I3, págs. 372 ss.; Álvarez ÁlvAREZ, H., Régimen jurídico del domicilio de las personas físicas, lex Nova, Valladolid, 2004, págs. 37 ss.

${ }^{29}$ A este respecto, vid., también, O’CAllaghan MuÑoz, X., Código Civil. Comentado y con jurisprudencia, Madrid, I996, págs. 82-83, considera que «el domicilio real se caracteriza por un elemento material, la residencia, y un elemento espiritual, la habitualidad que se caracteriza por ser normal y presumible para un futuro próximo». VÁzQuez IruZiBietA, C., Código Civil, Comentarios, notas y jurisprudencia, Madrid, 2007, págs. 94-95, alude asimismo al elemento material (residencia) y al elemento intencional (habitualidad).

${ }^{30}$ En este sentido, Albadalejo García, M., «Comentario al artículo 40 y al artículo 4I del Código Civil», en AA.VV., Comentario al Código Civil Y Compilaciones Forales, I.3, Madrid, I993, págs., 921 ss.

${ }^{31}$ En este sentido, AA.VV. (Moreno Quesada coord.), Curso de Derecho Civil I, Parte general Y Derecho de la persona, Valencia, I998, pág. I24.

${ }^{32}$ Al respecto, vid., la bibliografía recogida por AlbadAlejo GARCíA, M., «Comentario al artículo 40 y al artículo 4I del Código Civil», cit., págs. 92I SS.; ÁlvAREZ ÁlvAREZ, Régimen jurídico del domicilio de las personas físicas, cit., págs. 37 ss.

${ }^{33}$ De CASTRO, F., Derecho civil de España, II.I, Madrid, I952, pág. 450, citado por Álvarez ÁlvarEZ, Régimen jurídico del domicilio de las personas físicas, cit., págs. 38-39. En este sentido, PARRA LUCÁN, «Nombre y domicilio», cit., págs. 369 ss.

${ }^{34}$ Lacruz Berdejo, Elementos de Derecho Civil, I, Parte General del Derecho Civil, vol. II, Personas, Bosch, Barcelona, I990, págs. 212-213.
} 
Nos encontramos, por tanto, siguiendo a PARRÁ LUCÁN, ante un concepto jurídico de carácter legal, en la medida en que es la ley la que establece los criterios que deben tenerse en cuenta a la hora de valorar un lugar como sede de la persona: el derecho parte de un criterio realista para identificar el domicilio de la persona física, al definirlo como «el lugar de su residencia habitual». Pero al mismo tiempo el artículo 40 admite supuestos en los que domicilio y residencia habitual no coinciden, como el caso de los diplomáticos en el extranjero, cuyo domicilio es el último que hubieran tenido en territorio español (art. 40.2). En otros preceptos el domicilio es la dirección que la persona establezca en sus relaciones con los demás (así a efectos de notificación, art. 682 LEC, 24.3 Ley Arbitraje o 48 Ley General Tributaria...) o el lugar en que se reside (como ocurre en materia testamentaria para completar la voluntad del testador ex arts. 749 y 956 CC)... ${ }^{35}$

De acuerdo con todo lo anterior, los autores han establecido distintas clasificaciones del domicilio: ${ }^{36}$

a) En atención a sus efectos, el domicilio puede ser general o especial (o electivo): El general es el lugar que la ley considera como sede jurídica de la persona para la generalidad de las relaciones jurídicas. El especial o electivo es el lugar que eligen las personas para determinadas actuaciones con independencia de que residan o no en el mismo, como son el domicilio fiscal (para el pago de impuestos), el domicilio procesal (señalado a efectos de determinar la competencia de los tribunales) o el domicilio administrativo (que rige entre el administrado y la Administración).

b) En atención a la fuente u origen del domicilio, éste puede ser voluntario o legal (o necesario). El primero se corresponde con la residencia habitual, recogido en el art. 40 $\mathrm{CC}$, que es el que se establece libremente en función de la libertad de residencia del art. I9 de la Constitución. El legal o necesario, es el establecido por la ley como sede de la persona con independencia de que ésta resida o no habitualmente allí. Este domicilio es impuesto por la ley, bien en relación con el estado civil de las personas y su situación de dependencia respecto a otras (Ej. Los hijos no emancipados tienen el domicilio de sus padres, aunque por razones de estudio pueden no residir allí), o bien en función de su profesión o del cargo que desempeñan (Ej. El art. 40.2 CC respecto al domicilio de los diplomáticos que por razón del cargo residan en el extranjero). ${ }^{37}$

\section{El concepto de persona jurídica: fundamento y admisibilidad}

Delimitado el concepto de domicilio, el segundo de nuestro problemas es tratar de determinar en qué medida es posible retrotraer el concepto de persona jurídica al derecho romano.

\footnotetext{
${ }^{35}$ PARRA LuCÁN, «Nombre y domicilio», cit., págs. 369 ss.

${ }^{36}$ Al respecto, Álvarez Álvarez, Régimen jurídico del domicilio de las personas físicas, cit., págs. 42-43, quien señala también otras clasificaciones menores: en función de los derechos cuyo ejercicio determina el domicilio, puede distinguirse entre domicilio civil, mercantil o político; en función de si se determina por actos propios o atención a otras personas, el domicilio será absoluto (o propio) o relativo (o derivado); tomando en consideración el tiempo, podemos distinguir entre domicilio fijo, cuando la residencia en lugar fuera continua, o domicilio accidental, cuando la residencia supusiese un carácter supletorio para el cumplimiento de alguna obligación. Vid., asimismo, PARRA LuCÁn, «Nombre y domicilio», cit., 373 ss.; VÁZQuez IruZibietA, Código Civil, Comentarios, notas y jurisprudencia, cit., pág. 95.

${ }^{37}$ Sobre otros supuestos de domicilio legal previstos en la LEC de I88I y derogados por la vigente de 2000 como el domicilio de los comerciantes o de los empleados públicos, PARRA LUCÁN, «Nombre y domicilio», cit., 373 ss.; AA.VV. (Moreno Quesada coord.), Curso de Derecho Civil I, Parte general y Derecho de la persona, cit., pág. I24; Álvarez ÁlVAREZ, Régimen jurídico del domicilio de las personas físicas, cit., págs. 42-43.
} 
La dogmática moderna utiliza el concepto de persona jurídica para reconocer como sujeto de derechos y obligaciones a los entes colectivos formados por un conjunto de personas y a los conjuntos de bienes destinados a un determinado fin.

Sin embargo, el Derecho romano no conoció el concepto de persona jurídica. ${ }^{38}$ Es más, como indica DUFF, ni si quiera conocieron el término jurídico de persona que se empleaba simplemente para designar al hombre, al ser humano con independencia de su condición y sin un específico significado jurídico. Persona era tanto el hombre libre como el esclavo, de modo que el término no equivalía a sujeto de derechos ni tenía relación con la capacidad jurídica o la capacidad de obrar. En realidad cuando los romanos querían referirse al status o a la capacidad jurídica de un ciudadano empleaban el término caput y cuando querían manifestar la disminución de esa capacidad hablaban de capitis minutio. ${ }^{39}$

En relación con las entidades objeto de nuestro estudio, como indica ÁlvAREZ SUÁREZ, «los jurisconsultos romanos nunca abordaron el tema de si estas entidades poseían lo que hoy llamamos personalidad jurídica limitándose a analizar, a través de su método casuístico, si eran capaces de realizar determinados actos jurídicos de tal forma que, ni incluso en el derecho más tardío, se alcanzó una construcción jurídica clara al

\begin{abstract}
${ }^{38} \mathrm{Al}$ respecto, vid. las distintas posturas que sobre la personalidad jurídica del Estado, las colonias, los municipios, los colegios y de las diversas agrupaciones de base patrimonial como la herencia yacente, el fisco o las fundaciones son mantenidas, entre otros, por Bolze, A., Der Begriff der Juristischen Person, Stuttgart, I879, págs. I Ss.; VAUTHIER, M., Études sur les personnes morales dans le droit romain et dans le droit français, Bruxelles, Paris, I887, págs. II ss.; LieBnAM, W., Zur Geschichte und Organisation des Römischen Vereinswe-sens (drei untersuchungen), Leipzig, I890, págs. 233 ss.; KARLOWA, O., Römische Rechtsgeschichte, vol. II, Leipzig, I90I, págs. 59-69; Saleilles, R., De la personnalité juridique. Histoire et théories. Vingt-cinq leçons d'introduction à un cours de Droit civil comparé sur les personnes juridiques, Paris, I9I0, págs. 45-I6I; CZYHLARZ, K.R., Lehrbuch der Institutionen des römischen Rechtes, Prag, Wien, Leipzig, I902, págs. 77 ss.; FERRARA, F., Teoria delle persone giuridiche, (Iо ${ }^{\circ}$ libro de la obra Il Diritto civile italiano, inicialmente dirigida por P. Fiore y continuada por B. Brugi), $2^{a}$ edición revisada, Napoli, I923, págs. 22-44; DE SAVIGNY, F., Sistema de derecho romano actual (trad. esp. de J. Mesía y M. Poley), T. II, Madrid, I924, págs. 57-I35; SChNorr, L.-CARolsfeld, V., Geschichte der juristischen Person, I, München, I933, págs. I ss. y págs. I36 ss., entre otras; BANDini, V., Appunti sulle corporazioni romane, Milano, I937, págs. I77 SS.; TORRI, A.P., Le corporazioni romane. Cenno storico giuridico economico, $2^{a}$ edición, Roma, I94I, págs. I5 Ss.; ElIACHEVITCH, B., La personnalité juridique en droit privé romain, Paris, I942, págs. 5349; Dumont, F., Manuel de Droit Romain, I, Paris, I947, págs. 377 ss.; Von LÜBTOW, U., «Bemerkungen zum Problem der juristischen Person», en L'Europa e il diritto romano. Studi in memoria di P. Koschaker, II, Milano, I954, págs. 470 ss.; BucKLAND, W.W., A Text-Book of roman Law from Augustus to Justinian, $3^{\text {a }}$ edición, Cambridge, I963, págs. I73 ss.; ImPallomenI, G., s.v. «persona giuridica (Diritto romano)», en NNDI, XII, Torino, I965, pág. IO28; ORESTANO, Il problema delle fondazioni in Diritto romano, I, Torino, I959, págs. 3 ss.; idem, Il «problema delle persone giuridiche» in Diritto romano, I, Torino, I968, págs. 79-319; WALTZING, J.P., Ettude historique sur les corporations professionnelles chez les romanis depuis les origines jusqu'à la chute de l'Empire d'Occident, 3 vols., Roma, Ig68 (edición anastática de Bruxelles, I895), especialmente vol. II, págs. 43I SS.; SIBER, H., Römisches Recht in Grundzügen für die Vorlesung, II, Darmstadt, I968 (reimpresión de la edición de Berlin, I928), págs. 49-53; Russomanno, M.C., Curso de Instituciones de Derecho romano, I, Buenos Aires, I970, págs. 39-5I; Duff, P.W., Personality in roman private Law, New Jersey, I97I (reimpresión de la edición de New York, I938), págs. 5I-205; CARAmes Ferro, J.M., Instituciones de Derecho Privado Romano, I, $2^{\mathrm{a}}$ edición, Buenos Aires, I972, págs. I3I-I79; Álvarez SuÁREZ, U., Instituciones de Derecho Romano, III, Personas físicas y colectivas en el Derecho romano, Madrid, I977, págs. I93-276; DE ROBERTIS, F.M., Storia delle corporazioni e del regime associativo nel mondo romano, II, Bari, I97I, págs. 265 ss. y págs. 302 ss.; idem, Il fenomeno associativo nel mondo romano. Dai collegi della Repubblica alle corporazioni del Basso Impero, Roma, I98I (reimpresión de la edición de I955), págs. II-I2, pág. 73 y pág. 79; PASTORI, F., Gli istituti romanistici come storia e vita del diritto, Milano, I988, págs. 225-236; CATALAno, P., Diritto e persone. Studi su origine e attualità del sistema romano, I, Torino, I990, págs. I63I88; SuÁREZ BlÁZqueZ, G., Dirección y administración de empresas en Roma, $2^{a}$ edición, Vigo, 200I, págs. 42 SS.; HeRnANDo LeRA, J., «Persona jurídica», en Lecciones de la asignatura de Derecho Romano integradas en la Base de Conocimiento Jurídico de www.iustel.com, 2002, págs. I ss.; PENDÓN MELÉNDEZ, E., Régimen jurídico de la prestación de servicios públicos en Derecho Romano, Madrid, 2002, págs. 4I-6I y págs. 230-246; AleXANDER, L., Anstalten und Stiftungen Verselbständigte Vermögensmassen im Römischen Recht, Köln, 2003, págs. 3 Ss.; BLANCH NouguÉs, J.M., Régimen jurídico de las fundaciones en Derecho romano, Madrid, 2007, passim.
\end{abstract}

39 DufF, Personality in roman private Law, cit., págs. 24-26; IMPALLOMENI, s.v. «persona giuridica (Diritto romano)», cit., pág. I029; AlBANESE, s.v. «persona (Diritto romano)», en ED, 33, Varese, I983, págs. I69 ss.; Blanch Nougués, Régimen jurídico de las fundaciones..., cit., págs. I9 ss.; MAININO, G., «Dalla persona alla persona giuridica: la persona in Gaio e il caso delle 'Istituzioni' alimentari nell'esperienza romana», en S.D.H.I., 70, 2004, págs. 48I ss. 
respecto»..$^{40}$

En este sentido, afirma BLANCH NOUGUÉS siguiendo a ORESTANO, «los juristas romanos no partían de la elaboración de un concepto universal de 'persona jurídica' sino que actuaron a partir de la necesidad misma de identificar diversos centros de imputación de relaciones jurídicas en torno a los conceptos de res incorporalis, corpus y universitas»: ${ }^{4 \mathrm{~T}}$

a) Res incorporalis: como son el rebaño o la legión en tanto que se configuran como unidades integradas que no están unidas materialmente entre sí.

b) Corpus: relativo a los collegia, sodalitates, sodalicia o corpora, esto es, asociaciones de personas integradas en una unidad constituida para la consecución de los más diversos fines lícitos pero, sobre todo, para fines religiosos y profesionales.

c) Universitas: como realidad nacida a partir de la agrupación de elementos y relaciones jurídicas personales y patrimoniales como son los casos típicos de la herencia o de las civitates.

En estos supuestos, precisa BLANCH NOUGUÉS, «la labor de los juristas romanos es instrumental, en tanto que persiguen en esencia hacer posible la atribución de relaciones jurídicas a ciertas agrupaciones permanentes o al menos estables de personas constituidas como tales para el cumplimiento de fines de interés general». Pero en el seno de un ambiente intelectual que no sentía la necesidad de abstraer conceptos, estos juristas no fueron más allá en la elaboración de una dogmática acerca de las personas jurídicas. ${ }^{42}$

No obstante, como indica SAlEILlES, la jurisprudencia romana, reelaborada y sistematizada por la compilación justinianea sentó las bases para el ulterior desarrollo de la dogmática europea en esta materia y su labor de «conceptualización», iniciada en el marco de una sociedad que se articulaba, al igual que en la época justinianea, en torno a los dogmas cristianos, esto es, fuera del pensamiento casuístico de los juristas clásicos. ${ }^{43}$

En efecto, como sintetiza DE PABlo ConTRERAS, la categoría de persona jurídica es producto de un amplio proceso evolutivo, iniciado en los siglos medievales y que llega prácticamente hasta nuestros días, a lo largo del cual la doctrina ha debatido intensamente las razones de su fundamento y admisión, aglutinándose las distintas posturas, a través de distintas variantes, en torno a dos grandes teorías: la teoría de la ficción jurídica y la concepción antropomórfica. ${ }^{44}$

\footnotetext{
$4^{\circ}$ Álvarez SuÁreZ, Instituciones..., III, cit., págs. I98-I99, pág. 208 y págs. 272-273. En el mismo sentido, Russomanno, Curso..., I, cit., pág. 45, para quien, podemos extraer de las fuentes «que la noción de persona jurídica como ente abstracto con capacidad negocial análoga a la de los particulares fue en Roma producto de una lenta evolución y que su equiparación a las personas físicas no llegó a perfeccionarse»; PENDÓN MELÉNDEZ, Régimen jurídico..., cit., págs. 238 ss., que, en relación con la capacidad jurídica de las corporaciones que prestaban servicios públicos, considera que la misma fue consecuencia de una obra jurisprudencial que abarcó varios siglos a través de la cual se fueron gestando reconocimientos parciales e individuales y arbitrándose soluciones jurídicas que cobraron mayor relevancia según avanzaba la época imperial pero que ni si quiera en época justinianea llegará a culminar en su totalidad.

${ }^{41}$ Blanch Nougués, Régimen jurídico de las fundaciones..., cit., págs. 2I ss.; ORESTANO, Il «problema delle persone giuridiche»..., cit., págs. I22 ss.

${ }^{42}$ Blanch Nougués, Régimen jurídico de las fundaciones..., cit., págs. 2I SS.

${ }^{43}$ SAlEILles, De la personnalité juridique..., cit., pág. 46; ORESTANO, Il «problema delle persone giuridiche»..., cit., págs. I83-I84.

${ }^{44}$ De Pablo Contreras, P., «Las personas jurídicas», en AA.VV., Curso de Derecho Civil, I, Derecho Privado, Derecho de la Persona, $2^{a}$ edición, Madrid, 200I, capítulo 22, págs. 565 ss. Sobre las distintas teorías relativas a la persona jurídica, vid., SAlEILles, De la personnalité juridique..., cit., págs. 305-664; SCHNORR-CAROLSFELD, Geschichte der juristischen Person, I, cit., págs. I ss. y págs. I36 ss.; ElIACHEVITCH, La personnalité juridique..., cit., págs. 350-373; ORESTANO, R., Il «problema delle persone giuridiche»..., cit., págs. I-79; DufF, Personality in roman
} 


\section{III.I. La teoría de la ficción del Derecho}

Tiene su origen en los siglos medievales cuando los canonistas pretendieron conseguir que las colectividades religiosas y las causas pías fueran considerados como categorías distintas y separadas de los miembros individuales que las componían. Con este planteamiento, en el siglo XIII, Sinibalbo DEI FIESCHI, el Papa Inocencio IV, consiguió que en el Concilio de Lión (I245) se evitara que las ciudades pudieran ser objeto de una excomunión general y colectiva, como hasta entonces había defendido el Derecho Canónico mediante una forzosa interpretación de las fuentes romanas como D. 4.3.I5.I, advirtiendo que las universitates eran nomina iuris y no personarum. ${ }^{45}$

A partir de entonces, en cuanto personae ficticiae, las agrupaciones o entidades dotadas de un cierto interés público que contasen con el reconocimiento o autorización del poder eclesiástico o poder secular correspondiente, pudieron actuar en el tráfico jurídico como personas independientes de los miembros que las formaban. ${ }^{46}$

Avanzando en el tiempo, en el siglo XVI, ${ }^{47}$ aparecen en estado embrionario las sociedades anónimas bajo la forma de «Compañía de Indias» que consiguieron el privilegio de comerciar en régimen de monopolio en las lejanas tierras descubiertas y limitar su responsabilidad a las aportaciones de los socios. Esta limitación de la responsabilidad patrimonial, acabó por convertirse en una de las notas características de las personas jurídicas y supuso la desaparición del interés público para dar paso al interés particular de los socios. ${ }^{48}$

En el siglo XIX, ${ }^{49}$ influido por la idea kantiana que veía al hombre como sujeto de derechos y al Derecho como garante de la libertad externa de los individuos, SAVIGNY reforzó la «teoría de la ficción», calificando a las personas jurídicas de «sujetos artificiales» creados «por simple ficción» en virtud de la autorización del Estado soberano para el

private Law, cit., págs. 206-236; Girón TenA, J., Derecho de Sociedades, I, Parte General. Sociedades Colectivas Y Comanditarias, Madrid, I976, págs. I45 sS.; DE CASTRO, F., Formación y deformación del concepto de persona jurídica, Madrid, I984, passim; Albadalejo, M., Derecho Civil, I, Introducción y Parte general, I6a edición, Madrid, 2004, págs. 370 ss.; BlANCH Nougués, Régimen jurídico de las fundaciones..., cit., págs. 49 ss. y la bibliografía por ellos citada.

${ }^{45}$ DE CASTRO, Formación y deformación..., cit., págs. I46-I47. Sobre la consideración del enunciado de Sinibalbo como un antecedente de la teoría de la ficción defendida por Savigny y negada por Gierke, vid. la bibliografía citada en Blanch NouguÉs, Régimen jurídico de las fundaciones..., cit., págs.5I n. II6 y pág. 52.

${ }^{46}$ A juicio de Eliachevitch, La personnalité juridique..., cit., pág. 354, la persona ficta o la persona repraesentata de la Edad Media, no había alcanzado todavía el sentido moderno de personalidad jurídica, utilizándose para oponer la universitas como unidad al conjunto de los individuos que la componían. Tales términos, como indica Blanch NouguÉs, Régimen jurídico de las fundaciones..., cit., pág. 53 n. II8, sólo toman carta de naturaleza en las obras de los comentaristas de la Baja Edad Media.

${ }^{47}$ ORESTANO, R., Il «problema delle persone giuridiche»..., cit., págs. I3-I4, destaca la importancia que tuvieron en este siglo las reflexiones acerca de la condición jurídica de la persona como sujeto de derechos aportadas por los humanistas franceses.

${ }^{48}$ Por todos, De Pablo ConTreras, «Las personas jurídicas», cit., pág. 567.

${ }^{49}$ Con anterioridad, debemos reseñar otro hito importante en la configuración de la teoría de las personas jurídicas que fue la concepción iusnaturalista de las llamadas personas morales defendida por Grocio y Pufendorf. Como expone DE CASTRO, Formación y deformación..., cit., págs. I64 ss., para el primero, el individuo tenía un cuerpo físico, mientras que los pueblos, ciudades o reinos tenían un cuerpo moral; la universitas era una personalidad real dotada de un cierto spiritus que le hacía permanecer inmutable aunque cambiasen sus miembros. Por su parte, Pufendorf, parte de un concepto unitario de persona moralis que engloba tanto a los hombres (personae simplices), como a las agrupaciones de individuos (personae compositae), conforme al cual, las personas morales tienen una sustancia propia y no pueden calificarse de mera ficción. Vid., asimismo, ORESTANO, Il «problema delle persone giuridiche»..., cit., págs. I4-I5. No obstante, como recoge, BlanCH NouguÉs, Régimen jurídico de las fundaciones..., cit., pág. 56, esta teoría de las personas morales fue rechazada por los revolucionarios franceses de finales del siglo XVIII que descartaban toda idea de ente-persona jurídica interpuesto entre el Estado y el ciudadano. 
cumplimiento de un fin y señaló las barreras existentes entre los tipos básicos de interés para el Derecho civil: las asociaciones y las fundaciones, según «tuviesen un substrato personal visible o una existencia aún más ideal basada en su objeto».5

\section{III.2. La concepción realista o antropomórfica}

Surgió a finales del siglo XIX de la mano de otro importante jurista alemán, OTTO VON GIERKE, ${ }^{\text {,I }}$ que propuso abandonar la teoría de la ficción, al entender que las personas jurídicas no eran una pura creación abstracta del Derecho sino entidades que tenían una innegable naturaleza y presencia social, una vida propia e independiente de los sujetos que las formaban, de modo que el Derecho no procedía a una creación de tales entes, sino que se limitaba a reconocer su existencia y a establecer el régimen jurídico que les era aplicable, delimitando su ámbito de actuación..$^{52}$

En la actualidad, partiendo de este sustrato antropomórfico, ${ }^{53}$ se constata también la necesidad de control por parte del ordenamiento jurídico, no sólo regulando las condiciones y presupuestos para el reconocimiento de la personalidad jurídica a las entidades sociales preexistentes, sino también controlando su actuación concreta, una vez reconocidas, para evitar los abusos y fraudes, como prueba la doctrina del «levantamiento del velo», naciente en la práctica judicial americana y que ha llegado a los países europeos, consistente en que si la estructura formal de la persona jurídica se utiliza con una finalidad fraudulenta y de forma desajustada, los Tribunales pueden descartarla con la correlativa separación entre sus respectivos patrimonios..$^{54}$

Por otro lado, la admisión de una categoría general de persona jurídica como sujeto de derechos con capacidad jurídica, no excluye la necesidad de distinguir entre los distintos tipos de personas jurídicas existentes. Basta a este respecto leer algunos de los artículos comprendidos en el Capítulo II del Título II del Libro I de nuestro Código Civil. En efecto, el artículo 38 emplea el concepto genérico de personas jurídicas para indicar las

${ }^{50}$ SAVIgny, Sistema..., II, cit., \85, págs. 60 ss. El autor prefiere utilizar la expresión persona jurídica, empleada por primera vez por HeISE, A., Grundriss eines Systems des gemeinen Civilrechts, $3^{\mathrm{a}}$ edición, Heidelberg, I8I9, en lugar de persona moral, porque estas entidades no existen como personas sino para el cumplimiento de un fin jurídico. Sobre esta teoría y su recepción por la pandectística y los ius publicistas alemanes del siglo XIX, ORESTANO, Il «problema delle persone giuridiche»..., cit., pág, 2I SS.; DE CASTRO, Formación y deformación..., cit., pág. I72; FerRARA, Teoria delle persone giuridiche, cit., págs. 2I ss; BlanCH Nougués, Régimen jurídico de las fundaciones..., cit., pág. 58 ss.

${ }^{51}$ GiERKE, O., Das deutsche Genossenschaftsrecht, III, Berlín, I88I. Ya con anterioridad, BESLER, G., Volksrecht und Juristenrecht, Leipzig, I843, págs. I58 ss.

${ }^{2}$ Sobre esta teoría, vid. la bibliografía señalada por BLANCH NOUGUÉs, Régimen jurídico de las fundaciones..., cit., págs. 6I-62.

${ }^{33}$ Cfr. Blanch Nougués, Régimen jurídico de las fundaciones..., cit., págs. 64 ss., donde expone algunas de las principales teorías esgrimidas por la doctrina europea del siglo $\mathrm{XX}$, a través de las cuales constata la crisis que, en el momento actual, sufre el concepto de persona jurídica.

${ }^{54}$ STS de 24 de mayo de i984. Sobre la doctrina del «levantamiento del velo», por todos, PAZ-ARES, C., Sobre la infracapitalización de las sociedades, Madrid, I987, págs., I587 ss.; idem, «La sociedad mercantil: atributos y límites de la personalidad jurídica», en URíA, R.-MenÉndez, A., Curso de Derecho Mercantil, I, Madrid, I999, págs. 548 ss.; PANTALEÓN, F, «Comentario a la STS de 28-may. I984», en CCJC, 5, Madrid, I984, págs. II707 SS.; URÍA, R.-MENÉNDEZ, A. (Coord.), La sociedad mercantil: atributos y límites de la personalidad jurídica. Las cuentas en participación, Madrid, 200I, págs. 527 SS.; DíAZ CAMPMANY, E., La doctrina del levantamiento del velo de la persona jurídica en el proceso de creación del derecho, Barcelona, I996, passim; GARCIMARTín AlfÉREZ, F.J., «Derecho de sociedades: Problemas de ley aplicable», texto disponible en www.uam/derecho/privado/mercantil, págs. 56 ss.; DE PABlo Contreras, «Las personas jurídicas», cit., págs. 567-568; DE Ángel YAGÜEZ, R., La doctrina del «levantamiento del velo» de las personas jurídicas en la jurisprudencia, $5^{\text {a }}$ edición, Civitas, Cizur Menor, 2006, passim. 
facultades que se les atribuyen. ${ }^{55}$ En cambio, el art. 35 de nuestro CC enuncia la existencia en nuestro sistema jurídico de tres tipos fundamentales de personas jurídicas: las corporaciones, las asociaciones y las fundaciones. ${ }^{56} \mathrm{Y}$ el artículo 37 establece la misma especificación, respecto a la regulación de su capacidad civil. ${ }^{57}$

\section{El domicilio de las personas jurídicas en derecho romano}

Como hemos dicho, si bien los juristas romanos no elaboraron una teoría de la personalidad jurídica, sí que atribuyeron a determinadas entidades, cuya supervivencia no dependía de la supervivencia de sus miembros, capacidades concretas para ser titulares de determinados derechos, obligaciones y actuaciones procesales a través de una lenta evolución.

Así, por ejemplo, de acuerdo con HERNANDO LERA, el Populus romanus disponía de un patrimonio público, el aerarium, integrado por Diocleciano en el fiscus, administrado por el emperador y destinado a fines públicos, podía ser titular del ager publicus, vender, arrendar, aceptar herencias o legados, manumitir esclavos o convertirse en deudor o acreedor. $^{58}$ Las corporaciones reconocidas como lícitas, según nos indica PENDóN MELÉNDEZ, podían conceder créditos o endeudarse, sin que tales créditos o deudas se considerasen propios de cada uno de sus miembros, desde la época de Marco Aurelio podían recibir legados, tenían capacidad para manumitir esclavos o para litigar mediante representantes expresamente designados, según las disposiciones de su constitución. ${ }^{59}$ Y los municipios, como nos señala FERRARA, desde la época clásica tenían capacidad para adquirir y disponer de un patrimonio propio, administrado por un magistrado, podían defender sus intereses, designando a la persona que actuase en su nombre ante los tribunales y, a partir de la época postclásica, podían recibir herencias de cualquier persona. ${ }^{60}$

${ }^{55}$ Art. 38 CC: «Las personas jurídicas pueden adquirir y poseer bienes de todas clases, así como contraer obligaciones y ejercitar acciones civiles o criminales, conforme a las leyes y reglas de su constitución».

${ }^{56}$ Art. 35 CC: «Son personas jurídicas: $1^{\circ}$. Las corporaciones, las asociaciones y fundaciones de interés público reconocidas por la ley. Su personalidad empieza desde el instante mismo en que, con arreglo a derecho, hubiesen quedado válidamente constituidas. $2^{\circ}$. Las asociaciones de interés particular, sean civiles, mercantiles o industriales, a las que la ley conceda personalidad propia, independiente de cada uno de los asociados».

${ }^{57}$ Art. 37 CC: «La capacidad civil de las corporaciones se regulará por las leyes que las hayan creado o reconocido; la de las asociaciones por sus estatutos; y la de las fundaciones por las reglas de su institución, debidamente aprobadas por disposición administrativa, cuando este requisito fuera necesario».

${ }^{58}$ Hernado Lera, «Persona jurídica», cit., págs. I-2, precisa que el populus romanus se desenvolvía en la esfera de los intereses patrimoniales a través de los magistrados que actuaban, no como representantes, sino en virtud de su imperium o potestas y gozando de ciertos privilegios, por ejemplo, sus actos con los particulares no quedaban sujetos al ius civile, sino al derecho público en virtud de su soberanía y cuando litigaba, no lo hacía de acuerdo con la jurisdicción ordinaria, sino mediante un procedimiento extraordinario (D. 5.I.76; D. 4I.3.30 pr.; Gayo, Institutae, 2.II; D. 43.8.2.2) FERRARA, Teoria delle persone giuridiche, cit., págs. 22 SS.; PEROZZI, S., Istituzioni di Diritto Romano, I, Roma, I928, págs. 568 ss.; ImPALlomenI, s.v. «persona giuridica (Diritto romano)», cit., págs. IO28 ss.

${ }^{59}$ D. 3.4.I.7; D. 4.3.I.I; D. 3.4.7.2; D. 34.5.20(2I); D. 40.3.I. Pendón MelÉNDEZ, Régimen jurídico..., cit., pág. 230 ss.; VAUTHIER, Études sur les personnes morales dans le droit romain et dans le droit français, cit., págs. 38 ss.; BRUgi, B., Istituzioni di Diritto Romano, $3^{\text {a }}$ edición, Torino, I926, págs. 80-82; FerRARA, Teoria delle persone giuridiche, cit., págs. 30 ss.; Lo BIANCO, F.G., Storia dei collegi artigiani dell’impero, Bologna, I934, passim; PerozZI, Istituzioni de Diritto Romano, I, cit., págs. 570 ss.; SAlEILles, De la personnalité juridique..., cit., págs. 50 ss., págs. 70 ss. y págs. IO० ss.; De RoberTIS, Storia delle corporazioni..., II, cit., págs. 277 ss.; IMPALlomenI, s.v. «persona giuridica (Diritto romano)», cit., págs. IO28 ss.; HERNADO LERA, «Persona jurídica», cit., págs. 4-5.

${ }^{60}$ D. 8.I.I2; D. 40.4.I; D. 4I.2.I.22; D. 4.3.I5.I; C. I. 6.24.I2. FERRARA, Teoria delle persone giuridiche, cit., págs. 30 s.; VAUTHIER, Études sur les personnes morales dans le droit romain et dans le droit français, cit., págs. 7 SS.; SAleilles, De la personnalité juridique..., cit., págs. 50 ss., págs. 70 ss. y págs. IO० ss.; De RoberTIS, Storia delle corporazioni..., II, cit., págs. 277 ss.; PEROZZI, Istituzioni di Diritto Romano, I, cit., págs. 568-570; ELIACHEVITCH, 
A través de esta sumaria enumeración observamos que los juristas romanos atribuyeron a estas entidades reconocimientos parciales de capacidad para realizar determinados actos jurídicos. Y es precisamente el reconocimiento de esa capacidad la que hace plantearnos si estas entidades pudieron ser igualmente titulares de un domicilio propio e independiente del de sus miembros.

En sentido afirmativo se manifiesta SAVIGNY para quien, aunque la configuración del domicilio como la residencia estable no puede ser aplicable a estas entidades dado que la misma «se apoya sobre las relaciones de la vida natural del hombre», era necesario que se les designara un lugar, sobre todo, a efectos de determinar la jurisdicción a la que quedaban sometidas. ${ }^{6 \mathrm{I}}$ En la mayor parte de los casos, estima el autor, la vinculación que unía a esta entidad con el territorio resolvería la cuestión. Tal era el caso, por ejemplo, de las colonias, municipios o de los colegios que desarrollaban su actividad en un espacio territorial delimitado. ${ }^{62}$

En relación con estos colegios profesionales locales, escasa información podemos extraer de las fuentes que han llegado hasta nosotros, por lo que algunos autores se limitan a vincular el domicilio con el lugar donde tenían su local y prestaban su servicio. ${ }^{63}$

Más preciso se muestra WALTZING, afirmando que cada colegio profesional pertenecía a una ciudad determinada y que todos sus miembros pertenecían a la misma ciudad, bien por su origen, bien por su residencia. En su opinión, por tanto, en el alto imperio los colegios eran corporaciones comunales vinculadas a un municipio determinado y autorizados a prestar sus servicios en los límites de dicho territorio municipal. ${ }^{64}$

WALTZING argumenta su teoría mediante la interpretación del significado de las distintas denominaciones epigráficas de los colegios profesionales. De acuerdo con esta interpretación, el nombre de la corporación unido al nombre del municipio en genitivo o locativo expresaba la pertenencia legal del colegio a la ciudad y su cualidad de institución comunal. Y el mismo significado tenía el nombre del colegio unido al adjetivo de la ciudad. $^{65}$ Una tercera fórmula, menos frecuente, era la expresión «consistere» seguida del nombre de la ciudad, del nombre del lugar de reunión (schola o canaba) o del nombre del vicus donde el colegio tenía su sede y su local, expresiones que indicaban que sus miembros, podían ser originarios de ella (cives) y estar establecidos en la misma, o tener allí su domicilio siendo de otra ciudad (incolae) o, incluso, indicar a aquéllos que sólo tenían un mero establecimiento, como un taller o un almacén y que, por tanto, sólo estarían sujetos a la jurisdicción local. ${ }^{66}$

La personnalité juridique..., cit., págs. 57 SS.; IMPALlOMENI, s.v. «persona giuridica (Diritto romano)», cit., págs. IO28 ss.; HERNADO LERA, «Persona jurídica», cit., págs. 2-4.

${ }^{61}$ SAVIGNY, Sistema..., VI, cit., pág. 158.

${ }^{62}$ SAVIGnY, Sistema..., VI, cit., pág. I58.

${ }^{63}$ En este sentido, De RoberTis, Il fenomeno..., cit., pág. I97 y pág. 2io n. 3, vincula el domicilio del colegio al lugar donde presta servicios.

${ }^{64}$ WALTZING, Étude..., I, cit., pág. 349 y II, cit., págs. I74 ss.

${ }^{65}$ WALTZING, Étude..., II, cit., págs. I75-I76, señala que el locativo y el adjetivo son empleados de modo concurrente para los fabri tignuarii de Ostia (C.I.L. XIV. I05, I60, 296, 370, 371: «col.. fabrum tign. Ostis». En Altinum, encontramos las dos formas reunidas: «collegia fab. cent. dendr. Feltriae itemque Beruensium» (V. 207I). En Ariminum, leemos (XI. 377): «collegia fabr. cent. dendr. urb(ium) juridicatus ejuus».

${ }^{66}$ WALTZING, Étude..., II, cit., págs. I76-182. Señala, entre otros, como ejemplos del término consistere seguido de un nombre de lugar que no es una ciudad: C.I.L. III. 6I66: «vet(erani) et cives R(omani) cons(istentes) ad canab(as) leg(ionis) V Mac(edonicae)»; Seguido del nombre la ciudad para designar la residencia de extranjeros, diferenciando la residencia de hecho de la ciudadanía de la villa adquirida por la origo, VIII. 9250: «Rusg(unienses) et Rusg(uniis) consistentes». Aplicado a comerciantes romanos establecidos en las provincias de las que son incolae o sólo tienen un depósito de mercancías, C.I.L. X. I634: «Cultores Jovis Heliopolitani 
No obstante, concluye el autor, aunque los colegios estuvieran formados por extranjeros a la ciudad, estaban autorizados en los límites de la misma y eran instituciones comunales aunque la idea no se expresara con el término «consistere» e incluso cuando los colegios no acompañaran sus nombres con el locativo o el adjetivo de dicha ciudad. ${ }^{67}$

Además, analizando más detenidamente estas inscripciones con el término «consistere», WALTZING observa que, en algunas de ellas, junto a la indicación de la agrupación territorial menor (canaba, vicus o barrio, castellum) donde se tiene la sede, el local o el lugar de reunión, se señala también la ciudad de la que forman parte y en la que ejercen su profesión. Así, los remeros de Verona que desarrollaban su actividad sobre el lago de Garda, residían y tenían su lugar de reunión en Arelica, dependiente (vicus) de Verona. Es por esta razón que se llamaban collegium nautarum Veronensium Arilicae consistentium, indicando a la vez la ciudad de la que forman parte y su lugar de residencia. ${ }^{68}$ Del mismo modo los centonarios (fabricantes de tejidos) de Plasencia tenían su sede en un vicus de esta ciudad, Clastidium, de ahí que se llamasen collegium centonariorum Placentinorum consistentes Clastidi. ${ }^{69} \mathrm{O}$ cuando los comerciantes de vino se denominaban negotiatores vinarii Luguduni in canabis consistentes, indicaban la ciudad en la que se habían establecido para ejercer su comercio (Luguduni) y su lugar de reunión o el barrio donde estaban situados sus almacenes (in canabis). ${ }^{70}$

De acuerdo con estas interpretaciones, por tanto, no siempre el colegio tenía su domicilio en el lugar donde se encontraba su local de reuniones o su sede, sino en la ciudad, dentro de cuyos límites territoriales, había sido autorizado para prestar los servicios y a la que jurídicamente pertenecía el lugar donde se situaba ese local o sede.

Ello es producto de la transformación de los colegios profesionales en organismos públicos al servicio de la burocracia. En efecto, de acuerdo con Gayo (D. 47.22.4) en la época de las XII Tablas sólo se exigía para la constitución de una corporación que los estatutos no fueran contrarios al orden público. Pero desde finales de la República, la Lex Iulia de Collegiis prohibió la existencia de aquéllas cuyas actividades no fuesen de utilidad pública, exigiendo ad casum la obtención de una autorización senatorial. Y en los primeros siglos del Imperio los colegios profesionales que prestaban un servicio público, fueron transformados en organizaciones semipúblicas encargadas de desarrollar servicios públicos, cuya profesionalidad servía de garantía a los órganos de poder, hasta convertirse definitivamente,

Berytenses, qui Puteolis consistunt»; Seguido de la schola o lugar de reunión, C.I.L. VI. 404, 7458, 9404. Seguido del nombre del vicus, C.I.L. V. 40I7, 7357, 5446, 5447.

${ }^{67}$ WALtZing, Étude..., II, cit., págs. I74 ss. En esta misma línea, BANDINI, Appunti..., cit., págs. IO2 ss., afirma que la expresión consistere seguida del nombre del lugar indica la residencia de hecho de los miembros del colegio, pero señala que la misma tiene solamente una importancia geográfica para los miembros del colegio y para el colegio en su conjunto dado que, aunque el individuo resida en un determinado municipio, es independiente como profesional de la administración municipal y puede operar como funcionario de la administración central: «Consistere, por tanto, se refiere a la residencia de hecho en una ciudad pero, sobre todo, destaca la independencia para los miembros del colegio como profesionales, y del colegio en su conjunto, de la ciudad donde está el centro de desarrollo del servicio. Sobre el término consistentes y su identificación con los incolae, De Ruggiero, s.v. 'onsistentes' en Dizionario Epigrafico di Antichità Romane, cit., vol. II, págs. 620 ss., atribuye a los consistentes un grado de integración menor en la ciudad que la que tuvieron los incolae, los cuales podían llegar a ser equiparados a los cives originarii; PORTILlO MARTín, R., Incolae. Una contribución al análisis de la movilidad social en el mundo romano, Córdoba, I983, págs. 43-47, que dejando abierta la cuestión se decanta más bien por sospechar la existencia de una diferenciación entre ambos. En nuestra opinión, ambos términos, si bien podían coincidir, no siempre eran identificables. Por todos, LomAS SALMONTE, F.J., «De la condición social de los incolae con especial referencia a Hispania», en Habis, I8-I9, I987-I988, págs. 383 ss.; D’ESCURAC, P., «Origo et résidence dans le monde du commerce sous le Haut-Empire», en Ktèma, I3, I988, págs. 57-68.

${ }^{68}$ WALTZING, Étude..., II, cit., pág. I78. C.I.L. V. 4017.

${ }^{69}$ WALTZING, Étude..., II, cit., pág. I78. C.I.L. V. 7357. Los centonarios de Como tenían su curia o local en Clivium. C.I.L. V. 5446, 5447 .

${ }^{70}$ C.I.L. VI. 29722. WALTZING, Étude..., II, cit., pág. I80. 
a partir del siglo III de nuestra era, en organismo públicos y oficiales al servicio de la burocracia estatal. Esta transformación limitó la libertad en el establecimiento y traslado del domicilio social, al obligar a sus componentes a estar domiciliados en la ciudad donde prestaban el servicio y a no abandonarla y comportó que, a partir del siglo IV d. C., cada ciudad tuviera sus colegios. ${ }^{7 \mathrm{~T}}$

Sin embargo, con anterioridad a la Lex Iulia de Collegiis, no tenemos constancia de ninguna limitación o requisito domiciliario, e incluso con posterioridad a ella, existieron colegios que, bajo el subterfugio de ser religiosos, desarrollaban otras actividades eludiendo el requisito de la autorización. En estos supuestos, si bien es lógico pensar que la vinculación local que el ordenamiento jurídico tenía como referencia se identificaba con el lugar donde el colegio prestaba su servicio o tenía su centro de reuniones, no podemos descartar, ante la ausencia de fuentes, que su domicilio social fuera otro, libremente elegido y susceptible de modificación.

No queremos decir con ello que el domicilio social alcanzara en Roma un mayor grado de abstracción que el experimentado por el domicilio de las personas físicas, el cual, como hemos visto, no se desvinculó jamás de su elemento material. Lo que queremos poner de manifiesto es que, al igual que ocurría con el domicilio de las personas físicas, la posesión de un local o la prestación de servicios en un lugar no eran por sí solos suficientes para determinar el domicilio del colegio, siendo posible que el mismo tuviera una pluralidad de locales y que prestase sus servicios por igual en distintas ciudades.

En estos supuestos, convenimos con SAVIGNY ${ }^{72}$ que, cuando la vinculación territorial no fuera tan clara, es posible que el problema de su domiciliación pudiera venir resuelto a través de sus estatutos, es decir, que la voluntas de los miembros del colegio precisase el lugar de domiciliación o que la autoridad pública fuera competente para solventar la cuestión asignándole un domicilio. Incluso, en nuestra opinión, podría admitirse, con carácter excepcional, que pudieran ser titulares de una pluralidad de domicilios. Sin embargo, ante la ausencia de fuentes, nos movemos en el terreno de las meras conjeturas.

En relación con las agrupaciones de bienes, en Derecho Romano debemos hablar de la herencia yacente, el fisco y los antecedentes de nuestras actuales fundaciones. Respecto a la herencia yacente, esto es, la situación transitoria en la que se encuentra la herencia desde la muerte de causante hasta su aceptación por el instituido heredero, aunque existen algunas voces discrepantes, ${ }^{73}$ la mayor parte de la doctrina no la ha considerado como un ente con personalidad jurídica con vocación de continuidad en el logro de un fin, por lo que ni si quiera puede considerarse como una fundación impropia. Los autores la definen, siguiendo a BLANCH NOUGUÉS, como «un patrimonio en expectación, privado internamente de sujeto, pero que tiende a adquirirlo: es un patrimonio que fue de una persona y será de una persona, pero que en el intervalo está protegido hasta

${ }^{71}$ C. Theod. I0.3.5; II.I.24; I4.7.3; I2.I.I79.I; Novellae Valentiniani, 3.34.3; C. Theod. 7.21.3; I2.I9.I; I3.5.34; I4.7.II; I4.8.I; I4.27.3; I6.2.39; Novellae Maioriani, 7.3; Edict. Teodorico 64. Sobre esta evolución y la asignación de un domicilio coactivo a los miembros de las corporaciones, Lo BIANCO, Storia dei collegi artigiani dell'impero, cit., págs. 89 ss.; WALTZING, Étude..., II, cit., pág. I6I y págs. 208 ss., especialmente págs. 336-348; PEROZZI, Istituzioni di Diritto Romano, I, cit., págs. 57I ss.; De RoberTIS, Storia delle corporazioni..., II, cit., págs. I6o ss. y págs. I99 ss., entre otras; idem, Il fenomeno..., cit., págs. I57 Ss. y págs. I87 ss.; Pendón MeLÉndEZ, Régimen jurídico..., cit., págs. 220 ss., págs. 26I Ss. y págs. 273 Ss., especialmente, págs. 298.

${ }^{72}$ SAVIGny, Sistema..., VI, cit., págs. I58-I59. Sobre los estatutos y la sede social de las corporaciones, WAltZing, Étude..., I, cit., págs. 2io ss. y II, cit., pág. I62; DE RoBeRTIS, Storia delle corporazioni..., II, cit., págs. 26 ss., especialmente pág. 35; idem, Il fenomeno..., cit., págs. 65 ss. y pág. Io2 n. 3, indican que, junto a la propia sede o lugar de reunión (schola), los colegios podían ser beneficiados en ocasiones con una sede en edificios públicos o en algunos templos (C.I.L. II. IO23I; C. Theod. I0.3.5); Pendón MeLÉndeZ, Régimen jurídico..., cit., págs. 247 Ss.

${ }^{73}$ Cfr. CAStro SÁEnZ, A., La herencia yacente en relación con la personalidad jurídica, Sevilla, I998, pág. 236. 
que la expectación se realice. La certeza del sujeto futuro explica por qué el patrimonio no se disgrega ni se reduce a sus elementos, sino que como complejo unitario es mantenido por el Derecho objetivo mientras el nuevo sujeto no llega». ${ }^{74}$

En lo que concierne al fisco, aunque muchos han querido ver en el mismo un patrimonio autónomo tendente a la personificación jurídica, lo cierto es que este patrimonio nunca dejó de pertenecer al Estado o al Príncipe y cualquiera que sea la tesis sobre su naturaleza jurídica (caja privada del Príncipe, patrimonio del populus destinado a fines públicos...), el mismo no aparece en la vida real como una persona social. ${ }^{75}$

Finalmente, por cuanto se refiere a las fundaciones alimentarias imperiales que nacen con los emperadores Nerva y Trajano, en ocasiones este tipo de fundaciones se instituían obligando a las personas que habían recibido créditos del Estado, a que destinasen los intereses debidos por la suma prestada, a la manutención y alimentación de jóvenes que careciesen de recursos económicos. No se pueden, por tanto, considerar fundaciones en el sentido técnico del término ya que, en realidad, lo que hicieron los emperadores fue confiar ciertos bienes a determinadas ciudades con la obligación de aplicar los intereses a la alimentación de los necesitados sin que el emperador dejase en ningún momento de ser propietario de los mismos. Por otro lado, aunque podían constituirse por actos inter vivos, lo normal era que su constitución se realizase por actos de última voluntad. En este caso, el fundador preveía en su testamento un legado modal a favor de la institución (colegio religioso o ciudad) que se iba a encargar de cumplir la voluntad del testador, de acuerdo con los fines que éste había fijado, siendo el Estado el encargado de velar por la administración. ${ }^{76}$

En relación con las piae causae, denominación que al igual que la de venerabiles domus, fue acuñada definitivamente en el lenguaje de los justinianeos y que engloba unitariamente al conjunto de establecimientos de caridad y beneficencia de inspiración cristiana que florecieron por todo el Imperio Romano, la doctrina se muestra más dividida.

Como indica Blanch Nougués, dentro de las causas pías se comprenden propiamente, por un lado, las llamadas casas venerables dentro de las que se distinguen establecimientos dedicados a la beneficencia pública tales como albergues para peregrinos, asilos de ancianos, leproserías, orfelinatos u hospitales públicos. Y, por otro lado, en el concepto de piae causae se incluyen también los patrimonios legados por benefactores particulares pero administrados por los obispos o abades respectivos constituidos como fundaciones impropias destinadas al sustento de los pobres y al rescate de ciudadanos romanos hechos prisioneros y esclavos por los enemigos de Roma. ${ }^{77}$

Esto ha dado origen a que algunos autores consideren que las causas pías no tuvieron en Roma personalidad jurídica porque no dejaban de ser patrimonios pertenecientes a la Iglesia o a su fundador, destinados a la atención y cuidado de las personas más necesitadas, normalmente administrados por obispos, patriarcas, ecónomos o cartularios (Novela, I2O, caps. 5 y 6) y que en muchos textos legislativos aparecen vinculados a los monasterios. ${ }^{78}$

\footnotetext{
${ }^{74}$ Blanch NouguÉs, Régimen jurídico de las fundaciones..., cit., págs. 43-44, quien cita al respecto a FerRARA, Teoria delle persone giuridiche, cit., págs. I03-IO4; ORESTANO, Il problema delle fondazioni..., cit., pág. I77.

${ }^{75}$ Por todos, Eliachevitch, La personnalité juridique..., cit., págs. 33 Ss.; ORESTANO, Il «problema delle persone giuridiche»..., cit., pág, 262. Sobre los advocati fisci como defensores de los intereses del fisco, AGUdo RUIZ, A., El advocatus fisci en Derecho Romano, Madrid, 2006, passim.

${ }^{76}$ Hernando Lera, «Persona jurídica», cit., págs. 5-6.

${ }^{77}$ Blanch Nougués, Régimen jurídico de las fundaciones..., cit., págs. 73 ss.

${ }^{78}$ HernANDo LerA, «Persona jurídica», cit., págs. 5-6.
} 
No obstante, junto a los establecimientos dependientes y vinculados a la iglesia local o al monasterio, existieron casas subordinadas pero verdaderamente autónomas y otras fundadas por benefactores privados, las cuales eran administradas autónomamente por los rectores de las mismas, hasta el punto de que algunos autores consideran, a nuestro juicio con acierto, que Justiniano pretendió dotar a estas casas venerables de un verdadero derecho singular que las configuraba como centros autónomos personificados, dotados de un patrimonio propio y de capacidad jurídica y de obrar, siendo sus administradores unos meros órganos de las mismas ${ }^{79}$. En efecto, Justiniano les reconoce la capacidad para administrar bienes, la posibilidad de adquirir inter vivos, les concede derechos hereditarios, les responsabiliza de sus deudas y les admite capacidad procesal para el ejercicio de acciones. ${ }^{80}$

Por tanto, como indica BlaCH Nougués, sí que se puede apreciar en las mismas la atribución de una subjetivación jurídica, que asentó las bases para que en los siglos medievales, se desarrollase la reflexión sobre la personalidad jurídica de las fundaciones.

\section{El domicilio y la nacionalidad de las personas jurídicas en nuestro derecho positivo}

Admitida la existencia de la categoría de las personas jurídicas, a los efectos concretar su centro de imputación de derechos y obligaciones, deviene necesario establecerles un determinado domicilio. Nuestro Código Civil se refiere a la cuestión en su artículo 4I disponiendo que «cuando ni la ley que las haya creado o reconocido, ni los estatutos o las reglas de fundación fijaren el domicilio de las personas jurídicas, se entenderá que lo tienen en el lugar en que se halle establecida su representación legal, o donde ejerzan las principales funciones de su instituto».

De acuerdo con este artículo, entiende PAZ-ARES, el domicilio de las personas jurídicas será el establecido en su momento constitutivo y, sólo a falta de éste, de forma subsidiaria se debe atender al lugar en que se encuentra fijada la representación legal o donde se ejerzan sus funciones principales. ${ }^{82}$ No obstante, esta aplicación subsidiaria entra escasamente en juego, puesto que, como señala ALBADALEJO, las disposiciones específicas relativas a la constitución de los diversos tipos de personas jurídicas, se caracterizan por exigir de forma imperativa la determinación de un domicilio en el momento constitutivo, como contenido esencial de sus estatutos. A su vez, el domicilio viene constatado oficialmente en las hipótesis en las que la persona jurídica de que se trate deba hacer constar en Centros o Registros oficiales el lugar del mismo o su cambio haya de reflejarse en ellos o, simplemente, para cumplir ciertos trámites o para constituirse, estén fijados centros u oficinas cuya competencia se determine por razón del domicilio. ${ }^{{ }^{3}}$

79 Al respecto, cfr., BRUguI, Istituzioni di Diritto Romano, cit., págs. 82-87; FERRARA, Teoria delle persone giuridiche, cit., págs. 30 ss.; PerozZI, Istituzioni di Diritto Romano, I, cit., págs. 577 ss.; Impallomeni, s.v. «persona giuridica (Diritto romano)», cit., pág. I032; BLANCH NoUGUÉS, Régimen jurídico de las fundaciones..., cit., págs. 73 Ss.

${ }^{80}$ C. I. I.2.23.4; C.I. I.2.I; C. I. I.2.22 y 23; C. I. I.3.4I; C. I. I.3.4I.5 y 6.

${ }^{81}$ Blanch NouguÉs, Régimen jurídico de las fundaciones..., cit., págs. 73 ss.

${ }^{82}$ PAZ-ARES, «La sociedad mercantil: atributos y límites de la personalidad jurídica», cit., págs. 543 SS.; DE PABlo Contreras, «Las personas jurídicas», cit., pág. 572

${ }^{83}$ Albadalejo García, M., «Comentario al artículo 40 y al artículo 4I del Código Civil», cit., págs. 492-493. Vid. arts. 6, 7,8 y 9 e) LSA; 7 y I3 d) LSRL; 3 y I2.2 $2^{\circ}$ Ley General de Cooperativas; arts. I7 a 20 y I20 RRM; 92 LCCH; I8 f) Ley de Sociedades de Garantía Recíproca; arts. 6, 7.I ${ }^{\circ}$, Io a) y II.I ${ }^{\circ}$ c) Ley de Fundaciones, entre otros. PAZ-ARES, «La sociedad mercantil: atributos y límites de la personalidad jurídica», cit., págs. 434 ss., para quien, aunque estas normas parecen decantarse por el principio de unicidad del domicilio, lo cierto es que no 
Dicho esto, sin embargo, se observa que este criterio subsidiario es el genéricamente admitido por la legislación específica. A este respecto, por ejemplo, la Ley de Fundaciones establece que deben estar domiciliadas en España las fundaciones que desarrollen principalmente su actividad dentro del territorio nacional, precisando que dicho domicilio se ubicará en el lugar donde se encuentre la sede de su Patronato o bien en el lugar en que desarrollen principalmente sus actividades. ${ }^{{ }^{4}}$ Del mismo modo, la LOA establece que tendrán el domicilio en España las asociaciones que se constituyan con arreglo a dicha ley y habrán de domiciliarse en España las asociaciones que desarrollen principalmente sus actividades dentro del territorio español con independencia del lugar de su constitución y añade que las asociaciones que se constituyan conforme a esta ley podrán optar entre fijar el domicilio en el lugar de la sede de su órgano de representación o en el lugar donde desarrollen principalmente sus actividades. ${ }^{85}$

En cambio, una alternativa parcialmente distinta se recoge en la LSA, en la LSRL y en la LGC, que permiten optar entre el lugar en el que radique su principal establecimiento o explotación o en el que se halle el centro de su efectiva administración y dirección. ${ }^{86}$ Este criterio del centro efectivo de la administración y dirección, como señala PÉREZ ESCALONA, puede parece, a priori, preferible, sobre todo a la hora de solucionar los problemas derivados de una discordancia entre el domicilio registral (arts. 7. $\mathrm{I}^{\circ} \mathrm{b}$ y $28 . \mathrm{I}^{\circ} \mathrm{b}$ LOA) y el domicilio real. Sin embargo, entiende la autora, la protección de terceros en estos supuestos de discordancia no puede ser óbice para limitar la autonomía en la elección del domicilio de los socios porque, «a tales efectos, basta con facultar a dichos terceros para que puedan considerar como domicilio cualquiera de ellos (arg. ex. arts. 6.2 ${ }^{\circ}$ LSA, $7.2^{\circ}$ LSL y $\left.6.2^{\circ} \mathrm{LC}\right) \gg .^{87}$

Finalmente, en relación con el domicilio, mayor interés presenta la determinación de la nacionalidad de las personas jurídicas, en el bien entendido, como afirma PEÑA BERNALDO DE QUIROS, que la nacionalidad se aplica a las personas jurídicas sólo de modo traslaticio en cuanto pertenecen a la esfera de intereses nacionales de un Estado miembro. Por tanto, la nacionalidad se aplica a fin de determinar el ordenamiento jurídico que les es aplicable. $^{88}$

En este sentido, el artículo 9.II del Código Civil dispone que «la ley personal correspondiente a las personas jurídicas es la determinada por su nacionalidad y regirá en todo lo relativo a su capacidad, constitución, representación, funcionamiento, transformación, disolución y extinción».

prohíben la pluralidad pudiéndose admitir excepcionalmente que una entidad tuviera varios domicilios estatutarios.

${ }^{84}$ El art. 6.2 de la Ley de Fundaciones continúa diciendo: «Las fundaciones que se inscriban en España para desarrollar una actividad principal en el extranjero tendrán su domicilio estatutario en la sede de su Patronato dentro del territorio nacional». Y el art. 7.I, en relación a las fundaciones extranjeras establece: «Las fundaciones extranjeras que pretenden ejercer sus actividades de forma estable en España, deberán mantener una delegación en territorio español que constituirá su domicilio a los efectos de esta ley e inscribirse en el Registro de Fundaciones».

${ }^{85}$ art. 9. $\mathrm{I}^{\mathrm{O}}$ y $2^{\mathrm{o}}$ LOA.

${ }^{86}$ arts. 6.I ${ }^{\circ}$ LSA, 7.I ${ }^{\circ}$ LSRL y 3 LGC. Asimismo, el Reglamento 2I57/200I del Consejo Europeo de 8 de octubre del 200I, regulador de la Sociedad Anónima Europea, en su artículo 7 dispone que «el domicilio social de la sociedad europea deberá estar situado dentro de la Comunidad, en el mismo Estado miembro que su administración central».

${ }^{87}$ PÉREZ ESCALONA, S., La asociación y el derecho de sociedades: una revisión en clave contractual, Logroño, Madrid, 2007, págs. I05-107.

${ }^{88}$ Peña Bernaldo De Quiros, M., «Comentario al artículo 28 del Código Civil», en AA.VV., Comentarios al Código Civil y Compilaciones Forales, I.3, Madrid, I993, págs. 691 ss. En este sentido PAZ-ArES, «La sociedad mercantil: atributos y límites de la personalidad jurídica», cit., pág. 536, afirma que «la significación que tiene la nacionalidad en el ámbito de las personas jurídicas... actúa simplemente como mecanismo de selección de las normas aplicables tanto en su dimensión obligatoria como en su dimensión organizativa». 
Este problema de la nacionalidad se produce cuando uno de los elementos de la personalidad jurídica es extranjero, puesto que, resulta evidente, que si sus promotores o fundadores son españoles, se ha constituido en España, su centro de administración y su patrimonio está en nuestro territorio y todas sus actividades se desarrollan en el mercado español, esa persona jurídica está sometida al Derecho español.

No obstante, las nuevas realidades del tráfico comercial internacional, impulsado por la normativa europea, han dado origen a que no sea extraño que, por ejemplo, uno o varios elementos de una sociedad sean extranjeros, lo que plantea el interrogante de cuál es el Derecho aplicable, si el español o el extranjero.

Para resolver esta cuestión, como indica CASTILLA FERNÁNDEZ-FÁBREGAS, tradicionalmente se ha venido distinguiendo entre dos modelos: el denominado de sede real y el denominado modelo de constitución-incorporación. El primero supone que la concreción de la nacionalidad y, por tanto, la determinación de la ley aplicable a la persona jurídica, se lleva a cabo a través del territorio del estado en que se encuentra establecida su sede real, con independencia de que la persona jurídica se haya constituido o no conforme a la legislación de dicho Estado. El segundo modelo, por su parte, establece que la nacionalidad y la ley aplicable vienen determinadas por el Ordenamiento jurídico bajo el que dicha persona jurídica se ha constituido y no por el lugar donde se encuentre su sede real. ${ }^{89}$

Con el objeto de ilustrar mejor las diferencias entre ambos teorías PAZ-ARES ofrece el siguiente ejemplo: «Si una sociedad se ha constituido con arreglo al Derecho inglés, pero tiene su principal centro de operaciones en España, el criterio de la constitución obligará al ordenamiento español a reconocerla como sociedad inglesa. El criterio del domicilio obligará, por el contrario, a someterla al Derecho español, en cuyo caso, como la sociedad no se ha constituido con arreglo a él, al intérprete no le quedará más salida que calificarla como sociedad irregular y someterla al régimen de la sociedad colectiva y ello aunque se hubiese constituido como sociedad de capitales (arg. ex. art. I6 LSA y iI.3 LSRL)». ${ }^{9 \circ}$

A este respecto, el artículo 28 del Código Civil atribuye la nacionalidad española a las corporaciones, fundaciones y asociaciones, reconocidas por la ley y domiciliadas en España. Por su parte el art. I5 del Código de Comercio parece decantarse por el lugar de constitución lo que ha dado origen, como indica GARCIMARTín, a que la mayor parte de la doctrina, interpretando conjuntamente ambos artículos, defienda que en el Derecho español el criterio de atribución de la nacionalidad es el del domicilio-constitución, entendiendo unos por domicilio, el estatutario y, otros, la sede real. Conforme a esta tesis, por tanto, sólo serían españolas las entidades constituidas por el Derecho español y domiciliadas en España: «Según esta forma de ver las cosas, una sociedad es española si se ha constituido conforme al Derecho español, el cual exige que fije su domicilio en España (art. $28 \mathrm{CC}$ ); de ahí se deduce que una sociedad es española si se ha constituido conforme al Derecho español y además tiene su domicilio en España». ${ }^{9 \Gamma}$

${ }^{89}$ CASTilla FernÁndez-FÁbregas, R., «El traslado internacional del domicilio social», disponible en www.noticias.juridicas.com/articulos/50-Derecho\%20Mercantil/200207-285617361023I83I.html, págs. I-4. Sobre estos dos modelos, PAZ-ARES, «La sociedad mercantil: atributos y límites de la personalidad jurídica», cit., pág. 537; GARCimARTín AlfÉreZ, «Derecho de sociedades: Problemas de ley aplicable», cit., págs. 3 Ss.; BlancoMorAles, P., La transferencia internacional de la sede social, Pamplona, I997, págs. 40 ss. y págs. 64 ss., donde se analizan los argumentos esgrimidos a favor y en contra de ambos modelos.

${ }^{90}$ PAZ-ARES, «La sociedad mercantil: atributos y límites de la personalidad jurídica», cit., pág. 537.

${ }^{91}$ Garcimartín AlfÉREZ, «Derecho de sociedades: Problemas de ley aplicable», cit., págs. 20-2I. Aunque la teoría del autor está pensada para las sociedades, consideramos que se pueden dar a sus conclusiones carácter general. 
Esta es la postura defendida por PEÑA BeRnAldo DE QUiRos, para quien el problema radica en que el Código Civil sigue en su planteamiento la idea de que las personas jurídicas están vinculadas al país cuyo ordenamiento les da vida. En consecuencia, salvo que se disponga otra cosa en Ley especial o Tratado, el Ordenamiento español sólo atribuye la nacionalidad española a organizaciones domiciliadas en España. Además, no reconoce personalidad jurídica regular a las constituidas como tales conforme a una ley extranjera pero que hayan de estar inicialmente domiciliadas en España. ${ }^{92}$

Pero, como constata PAZ-ARES, si ambos requisitos se exigen cumulativamente, ello supone que, a falta de uno de los dos elementos, esas entidades ni serían españolas, ni serían extranjeras y carecían de ley aplicable, lo cual es un absurdo. El error de este planteamiento, profundiza GARCIMARTín, reside en que se confunde el problema conflictual, esto es, la determinación de la lex societatis, y el problema material, es decir, los requisitos materiales exigidos para considerar que la entidad está válidamente constituida, como es la domiciliación en un determinado lugar. En consecuencia, para determinar la ley aplicable se debe atender a uno de los criterios solamente: «Si el criterio es el de la constitución, la referencia que se puede hacer al domicilio, que será el estatutario, es como mero sustituto de aquél (como forma de expresar la voluntad de los socios de constituirse conforme al Derecho español)... Y esto es lo que, de una forma algo oscura, nos quiere decir el art. 28 CC... Si el criterio es el domicilio qua sede real, lo determinante es única y exclusivamente este último elemento (la sede real)... Sólo cuando hemos determinado la ley aplicable, podemos precisar si la entidad está válidamente constituida conforme a la misma, exigiendo el art. $28 \mathrm{CC}$, entre otros requisitos, que fije su domicilio estatutario en España».93

GARCIMARTÍN, por tanto, se decanta a favor del criterio de constitución, en función del cual, son españolas las sociedades constituidas conforme al Derecho español o las que sus socios (rectius, personas que la constituyen) han querido constituir conforme al Derecho español. Sólo en el caso de que en los términos del contrato no resulte claro la voluntad de constituirse conforme a nuestro Derecho, deberá atenderse a la localización en España de su domicilio estatutario (art. 4I CC)..$^{94}$

En el mismo sentido se manifiesta PÉREZ EsCALONA en relación con las asociaciones, afirmando que: «el criterio del domicilio sirve para determinar si una sociedad española se ha constituido o no correctamente y, en todo caso, como criterio subsidiario de atribución de la nacionalidad siempre que las partes no hayan elegido el Derecho al que

${ }^{92}$ Peña Bernaldo De Quiros, M., «Comentario al artículo 28 del Código Civil», cit., págs. 69i ss., en cuya opinión, la LSA no cambia ésto, sino que lo radicaliza.

${ }^{93}$ Garcimartín AlfÉreZ, «Derecho de sociedades: Problemas de ley aplicable», cit., págs. 22-23. La confusión entre el problema conflictual y el material es, asimismo, señalada por PAZ-ARES, «La sociedad mercantil: atributos y límites de la personalidad jurídica», cit., págs. 537 Ss.; PÉREZ ESCALONA, La asociación..., cit., pág. IO4.

${ }^{94}$ Garcimartín AlfÉREZ, «Derecho de sociedades: Problemas de ley aplicable», cit., págs. 8 ss., y págs. I9-20. En contra del criterio de la sede real señala que mientras el lugar de incorporación o constitución es fácil de localizar en todos los supuestos, la sede real puede ser difícil de determinar en sociedades con estructura económica compleja; que una sociedad constituida conforme al derecho de un estado y que tenga su sede real en otro, carecerá de personalidad jurídica en éste, con todos los problemas que ello comporta; que este modelo constituye un obstáculo para las actividades de las empresas en el mercado internacional, impidiendo que busquen su constitución conforme al Derecho que más les favorezca y dificultando los traslados de la sede real, ya que esto supondría un cambio de la ley aplicable. Por ello, considera más acertado el criterio de la constitución, el cual es la solución que en buena medida viene exigida por el Derecho comunitario; es la solución más acorde con nuestro derecho histórico; es la que subyace a la jurisprudencia del TS y de la DGRN; es la más ajustada a las tendencias de nuestro derecho comparado; y la que mejor responde a las necesidades del tráfico y la que mejor justificación encuentra en términos sustantivos. En relación con la reciente jurisprudencia del Tribunal Europeo que contradice la teoría de la sede real, del mismo autor, «La Sitztheorie es incompatible con el Tratado CEE (algunas cuestiones del Derecho nacional iluminadas por la STJCE de 9 de marzo de I999", en $R D M, 323$, I999, págs. 645 Ss.; «La sentencia del TJCE ‘Überseering': se podrá decir más alto, pero no más claro», texto disponible en www.uam/derecho/privado/mercantil, págs. I-I8, donde el autor constata que este tribunal ha considerado que la teoría de la sede real es incompatible con la normativa europea sobre la libertad de establecimiento (arts. 43 y 48 CE) Cfr. STJCE C-212/97 y C-208/00. 
desean someter la sociedad. Pero para averiguar, prima facie, si una asociación se sujeta o no a la lex societatis española es preciso recurrir al criterio de la constitución, en definitiva, porque la elección de la lex societatis... es una decisión que debe corresponder a las partes. Sólo a falta de esta voluntad, por tanto, a una asociación domiciliada (cláusula de cierre) en España (y por tanto válidamente constituida conforme a la Ley española) le será aplicable el Derecho español».95

No obstante, este criterio de la constitución se confronta, a priori, con el art. 5 LSA y el art 6 LSRL, que establecen que serán españolas las sociedades que tengan su domicilio en territorio español con independencia del lugar de constitución, ${ }^{96}$ lo que ha conducido a un importante sector doctrinal a aceptar, como criterio de atribución de la nacionalidad para las sociedades de estructura corporativa, el de la sede real que viene a identificarse con el lugar en que la sociedad tienen su centro principal de actividades. ${ }^{97}$

Pero esta contradicción, a juicio de GARCIMARTín, es sólo aparente. Tales preceptos no alteran la regla general del criterio de constitución, limitándose a establecer una excepción a dicha regla para prevenir situaciones fraudulentas: «cuando la sociedad sea objetivamente española deberá constituirse conforme al Derecho español. El supuesto objetivo en el que están pensando esos preceptos no es el de una empresa internacional cuya sede principal se encuentra en España, sino el de una empresa nacional. En este sentido, el supuesto es análogo al previsto en el art. 3.3 del Convenio de Roma sobre la ley aplicable a las obligaciones contractuales... Según este precepto, cuando todos los vínculos significativos del contrato se localizan en un solo país, el legislador no permite que las partes escojan un Derecho extranjero...». Aplicando este principio al derecho societario esos artículos (5 LSA y 6 LSRL) «se encargan sencillamente de constatar que, cuando tanto las relaciones internas como las relaciones externas se localicen en nuestro país, la sociedad debe constituirse conforme al Derecho español»..$^{8}$

Insistiendo en este planteamiento, BLANCO-MorALES afirma que la exigencia de establecer su domicilio en España es la consecuencia de la constitución de la sociedad conforme a la ley española. En su opinión, las LSA y LSRL dicen más de lo que se piensa puesto que, al hacer referencia al domicilio con independencia del lugar de constitución,

${ }^{95}$ PÉREZ EsCAlonA, La asociación..., cit., págs. I03-I05, con copiosa bibliografía sobre la materia.

${ }^{96}$ Art. 5 LSA: «I. Serán españolas y se regirán por la presente Ley todas las sociedades anónimas que tengan su domicilio en territorio español, cualquiera que sea el lugar en que se hubieran constituido. 2. Deberán tener su domicilio en España las sociedades anónimas, cuyo principal establecimiento o explotación radique dentro del territorio». En idénticos términos se expresa el art. 6 LSL para este tipo de sociedades.

${ }^{97}$ Así, PRETEL, «Nacionalidad y domicilio de las sociedades mercantiles», en AAMN, XXX.I, I99I, págs. I79 ss.; Olivencia, M., «Nacionalidad y domicilio de las sociedades anónimas», en ASN, 7, I993, págs. 502 ss.; SÁnChez CAlero, F., «La nacionalidad de las sociedades anónimas», en RDS, I, I993, págs. 45 ss.; idem, Instituciones de Derecho Mercantil, I, Introducción, Empresa y Sociedades, I9 ${ }^{a}$ edición, Madrid, I996, págs. 270 ss. y págs. 325-326; DE PABLo CONTRERAS, «Las personas jurídicas», cit., pág. 573. Los argumentos a favor de la sede real son que este criterio previene el fraude ya que asegura el respeto a la política legislativa del Estado más afectado por su actividad y el hecho de que, en los casos típicos, la localización de la sede real coincide con la localización de la mayoría de los intereses de todos los afectados: accionistas, acreedores, trabajadores, consumidores y Estado.

$9^{8}$ Garcimartín AlféreZ, «Derecho de sociedades: Problemas de ley aplicable», cit., págs. 25 ss., con abundantes argumentos a favor de su teoría entre los que destaca, de nuevo, la jurisprudencia del TJCE y con un detenido análisis sobre el traslado del domicilio social al extranjero como expresión de la voluntad de modificar la nacionalidad de la sociedad (págs. 88 ss.), tema sobre el que incide en «El traslado del domicilio social al extranjero. Una visión facilitadora», en RDS, I6, 200I, citado por CASTILLA FERNÁNDEZ-FÁBREGAS, «El traslado internacional del domicilio social», cit., pág. 4. Sobre la cuestión, vid., también, PeÑA BERnALDo De Quiros, «Comentario al artículo 28 del Código Civil», cit., págs. 698 ss.; BLANCO-MORALES, La transferencia internacional de la sede social, cit., págs. I2o ss.; SANDRO VILLA, D., La transferencia internacional de la sede social en el espacio europeo, Madrid, 200I, passim; FernÁndeZ DeL POZO, L., «Domicilio y nacionalidad de la SE: traslado internacional del domicilio de la SE. La publicidad registral de la SE», en AA.VV., La sociedad anónima europea: régimen jurídico societario, laboral y fiscal, Madrid, 2004, págs. I2I-278. 
están aludiendo al domicilio estatutario. Se trata de obligar a las sociedades constituidas según la ley española a que tengan, al menos de inicio, su sede estatutaria y real en España (pensemos en las sociedades en proceso de constitución). Por ello, la sociedad constituida conforme a las leyes españolas con domicilio estatutario en España, cuya sede real radique en el extranjero, es una sociedad española sometida a las leyes españolas. ${ }^{99}$

En nuestra opinión, los autores que defienden la teoría del domicilio confunden un criterio subsidiario con el criterio principal. Nuestro Código Civil considera españolas las personas jurídicas que estén constituidas conforme al mismo y a las disposiciones a las que éste remite (arts. 35 ss. CC), exigiendo como uno de los requisitos para su válida constitución que tengan su domicilio en nuestro territorio.

En consecuencia, convenimos con PAZ-ARES, en que el criterio establecido es el de la constitución, quedando reducida la exigencia de la domiciliación en España a una exigencia material de la validez o regularidad de la constitución. Además, continúa el autor, si los arts. 5.I LSA y 6.I LSRL se decantasen por el domicilio, estos preceptos deberían considerarse derogados por los arts. 43 y 48 del Tratado de Ámsterdam (antes arts. 52 y 58 del Tratado CE). El domicilio al que se refieren tales preceptos es el estatutario y no el real, de modo que las diferencias entre la teoría de la constitución-domicilio y la teoría de la constitución-incorporación se acortan paso a paso porque ambas se basan en el principio de autonomía privada. ${ }^{100}$

\section{Conclusiones}

$\mathrm{I}^{\mathrm{o}}$. En el Derecho romano con el término domicilium se indicaba el lugar donde una persona había establecido su residencia permanente con independencia de toda modalidad de propiedad o habitación y que constituía, con carácter general, el centro de sus actividades vitales y negociales. La estabilidad inherente al domicilio venía concretada por el establecimiento efectivo y por la voluntad actual de permanencia.

$2^{\circ}$. En el derecho intermedio se continuaron exigiendo los dos requisitos de la residencia y de la intención pero dotando de una mayor protagonismo a esta última, dando lugar a un proceso de abstracción, recogido en el art. 40 CC que configuró al domicilio como la sede jurídica de la persona para la imputación de sus derechos y obligaciones, concretada por las distintas leyes en función de los fines que se pretenden conseguir, siendo el medio principal - pero no exclusivo- de dicha localización jurídica su residencia habitual.

$3^{\circ}$. Los juristas romanos no elaboraron una dogmática sobre la persona jurídica cuyo reconocimiento como sujeto de derechos independiente de sus componentes es fruto de un proceso evolutivo, iniciado en los siglo medievales y que llega prácticamente hasta nuestros días, a lo largo del cual la doctrina ha debatido intensamente las razones de su fundamento y admisión, basculando las distintas posturas en torno a dos grandes teorías: la teoría de la ficción jurídica (las personas jurídicas son creaciones del Derecho) y la concepción antropomórfica (las personas jurídicas son realidades existentes que el Derecho se limita a reconocer y a regular su ámbito de actuación).

$4^{\circ}$. Los juristas romanos atribuyeron a algunas entidades suprapersonales reconocimientos parciales de capacidad para realizar determinados actos jurídicos, cuyo domicilio venía concretado, a efectos de determinar la jurisdicción a la que quedaban

\footnotetext{
${ }^{99}$ BlAnCO-Morales, La transferencia internacional de la sede social, cit., págs. IO2 ss.

${ }^{100}$ PAZ-ARES, «La sociedad mercantil: atributos y límites de la personalidad jurídica», cit., págs. 537 Ss.
} 
sometidas, en virtud de la vinculación territorial de dicha entidad o, en su defecto, a través de sus estatutos o mediante la designación de la autoridad pública competente.

$5^{\circ}$. En nuestro derecho positivo, las normas específicas regulan el domicilio de las diferentes personas jurídicas aplicándose subsidiariamente el lugar en que se halle establecida su representación legal o donde ejerzan sus principales funciones ex art. 4I CC, considerando españolas aquéllas constituidas conforme al Derecho español que, entre otros requisitos, exige que estén domiciliadas en nuestro territorio ex art. $28 \mathrm{CC}$. 